\section{(A) Check for updates}

Cite this: Dalton Trans., 2018, 47 12684

\title{
Coordination of arenes and phosphines by charge separated alkaline earth cations $\dagger$
}

\author{
Lucia Garcia, ${ }^{a}$ Mathew D. Anker, ${ }^{a}$ Mary F. Mahon, ${ }^{\star a}$ Laurent Maron ${ }^{\star b}$ and \\ Michael S. Hill (D) *a
}

\begin{abstract}
Generation of $\beta$-diketiminato group 2 cations, [( $\left.\left.{ }^{\mathrm{Me}} \mathrm{BDI}\right) \mathrm{Ae}\right]^{+}$and $\left[\left(^{t-\mathrm{Bu}} \mathrm{BDI}\right) \mathrm{Ae}\right]^{+}\left({ }^{\mathrm{Me}} \mathrm{BDI}=\mathrm{HC}\{(\mathrm{Me}) \mathrm{CN}-2,6-\mathrm{i}-\right.$ $\left.\mathrm{Pr}_{2} \mathrm{C}_{6} \mathrm{H}_{3}\right\}_{2} ;{ }^{t-\mathrm{Bu}} \mathrm{BDI}=\mathrm{HC}\left\{(t-\mathrm{Bu}) \mathrm{CN}-2,6-i-\mathrm{Pr}_{2} \mathrm{C}_{6} \mathrm{H}_{3}\right\}_{2} ; \mathrm{Ae}=\mathrm{Mg}$ or $\mathrm{Ca}$ ), in conjunction with the weakly coordinating anion, $\left[\mathrm{Al}\left\{\mathrm{OC}\left(\mathrm{CF}_{3}\right)_{3}\right\}_{4}\right]^{-}$, allows the characterisation of charge separated alkaline earth $\eta^{6}-\pi$ adducts to toluene or benzene when crystallised from the arene solvents. Addition of 1,4-difluorobenzene to $\left[\left({ }^{\mathrm{Me}} \mathrm{BDI}\right) \mathrm{Mg}\right]^{+}$results in the isolation of $\left[\left({ }^{\mathrm{Me}} \mathrm{BDI}\right) \mathrm{Mg}\left(1,4-\mathrm{F}_{2} \mathrm{C}_{6} \mathrm{H}_{4}\right)_{3}\right]^{+}$in which the fluorobenzene molecules coordinate via $\kappa^{1}-\mathrm{F}-\mathrm{M}$ interactions. Although DFT analysis indicates that the polyhapto arene binding to $\mathrm{Mg}$ is effectively electrostatic in origin, the interactions with $\mathrm{Ca}$ ( $\mathrm{Sr}$ and $\mathrm{Ba}$ ) are observed to invoke small but significant $\pi$ overlap of the arene HOMOs with the alkaline earth valence $n d$ orbitals. Reaction of triphenylphosphine with $\left[\left({ }^{\mathrm{Me}} \mathrm{BDI}\right) \mathrm{Mg}\right]^{+}$and $\left.\left[{ }^{(t-B u} \mathrm{BDI}\right) \mathrm{Mg}\right]^{+}$in toluene solvent allows the isolation of the respective terminally coordinated magnesium-phosphine adducts. The resultant $\mathrm{Mg}-\mathrm{P}$ bond lengths [2.5972(13), 2.6805(12) Å] are comparable to those previously observed in magnesium derivatives of terminal but formally anionic phosphide ligands, while the effectively electrostatic nature of the bonding is supported by DFT calculations.
\end{abstract}

Received 30th July 2018,

Accepted 15th August 2018

DOI: $10.1039 / c 8 d t 03124 j$

rsc.li/dalton tures and aggregation states adopted by a wide variety of organometallic, amido or phenoxy group 2 derivatives. ${ }^{13-21}$ In all such instances, however, the arene or $\pi$-substituent is a component of a more complex anion and benefits from the entropic advantage afforded by its intramolecular disposition. Despite their widespread biological significance, however, definitive structural characterisation of intermolecular interactions between $\mathrm{Mg}$ or $\mathrm{Ca}$ and neutral arenes has proven elusive, such that until very recently (vide infra) the only structurally authenticated examples of molecular species to feature intermolecular Ae- $\pi$ interactions in the solid state were provided by Hanusa's bis(trimethylsilyl)butadiyne adduct of decamethylcalcocene (III) ${ }^{22}$ and various serendipitously crystallised benzene and toluene solvates of barium derivatives. ${ }^{23}$

Similarly, the absence of filled and appropriately energetic $\pi$ symmetric $d$ orbitals at the hard Lewis acid centres of typical group 2 compounds provide a poor complement to the soft $\sigma$ donor character of typical phosphine ligands. Magnesium in its common +2 oxidation state, for example, behaves as a typical hard acid and, thus, displays only a very low affinity for coordination by phosphine bases. While Lehmkuhl and coworkers established by solution NMR methods that $\mathrm{PMe}_{3}$ and $\mathrm{Me}_{2} \mathrm{P}\left(\mathrm{CH}_{2}\right)_{2} \mathrm{PMe}_{2}$ form labile adducts with $\left[\left(\eta^{5}-\mathrm{C}_{5} \mathrm{H}_{5}\right)_{2} \mathrm{Mg}\right]$ over 30 years ago, ${ }^{24}$ and a variety of covalently bonded magnesium phosphides have been structurally characterised to contain ionic inter- and intramolecular $\mathrm{Mg}-\mathrm{P}$ bonds,${ }^{25-35}$ confirmatory evidence for the persistence of $\mathrm{Mg}-\mathrm{PR}_{3}$ interactions in the 


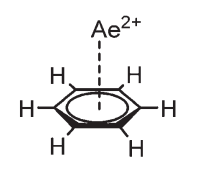

$\mathrm{Ae}=\mathrm{Mg}(\mathrm{I}), \mathrm{Ca}(\mathrm{II})$

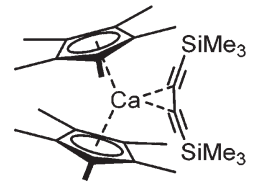

(III)

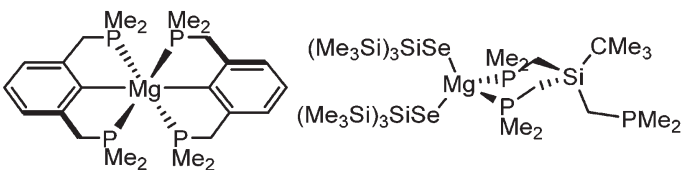

(IV)

(v)



${ }_{\text {Dipp }}^{\text {Dipp }}$

(VI) $\quad\left(\right.$ Dipp $\left.=2,6-i-\mathrm{Pr}_{2} \mathrm{C}_{6} \mathrm{H}_{3}\right)$

(VII)

solid state is very rare. Crystallographic characterisation is limited to the octahedral complex $\left[\mathrm{Mg}_{2}\left\{\mathrm{C}_{6} \mathrm{H}_{3}-2,6-\left(\mathrm{CH}_{2} \mathrm{PMe}_{2}\right)_{2}\right\}_{2}\right]$ $(\mathbf{I V})^{36}$ and the adduct $\left[\mathrm{Mg}^{37}{ }_{2} \cdot\right.$ TRMPSI] $($ TRMPSI $=$ tris-tert-butylsilane) (V) ${ }^{37}$ The maintenance of Mg-P interactions in these molecules, however, benefit respectively from incorporation of the phosphorus donors into a covalently bonded aryl ligand and from the thermodynamic advantage provided by the polydentate TRMPSI ligand. Examples of terminal phosphine to magnesium coordination, thus, remain structurally unauthenticated.

In 2018, and while the current study was in progress, Harder and co-workers described the isolation of several cationic $\left.\left[\left({ }^{\mathrm{Me}} \mathrm{BDI}\right) \mathrm{Ae}\right]\right]^{+}\left({ }^{\mathrm{Me}} \mathrm{BDI}=\mathrm{HC}\left\{(\mathrm{Me}) \mathrm{CN}-2,6-\mathrm{i}-\mathrm{Pr}_{2} \mathrm{C}_{6} \mathrm{H}_{3}\right\}_{2} ; \mathrm{Ae}=\right.$ $\mathrm{Mg}$ or $\mathrm{Ca})$ complexes as contact ion pairs of the $\left[\mathrm{B}\left(\mathrm{C}_{6} \mathrm{~F}_{5}\right)_{4}\right]^{-}$ anion. ${ }^{38}$ These cations are evidently extremely potent Lewis acids coordinating benzene, 3-hexyne and even hexamethyldisiloxane. $^{39}$ The benzene adducts, $\left[\left({ }^{\mathrm{Me}} \mathrm{BDI}\right) \mathrm{Mg} \cdot \mathrm{C}_{6} \mathrm{H}_{6}\right]^{+}[\mathrm{B}$ $\left.\left(\mathrm{C}_{6} \mathrm{~F}_{5}\right)_{4}\right]^{-}(\mathbf{V I}$; shortest $\mathrm{Mg} \cdots \mathrm{C}$ distance $=2.367(2) \AA)$ and $\left[\left({ }^{\mathrm{Me}} \mathrm{BDI}\right) \mathrm{Ca} \cdot \mathrm{C}_{6} \mathrm{H}_{6}\right]^{+}\left[\mathrm{B}\left(\mathrm{C}_{6} \mathrm{~F}_{5}\right)_{4}\right]^{-}$(VII, shortest $\mathrm{Ca} \cdots \mathrm{C}$ distance $=$ $2.909(2) \AA)$ were crystallographically characterised to display $\eta^{3}$ and $\eta^{6}$ binding, respectively, albeit both species also retain notably short Ae $\cdots \mathrm{F}-\mathrm{C}$ contacts to the weakly coordinating



Our own interest in these phenomena was prompted by our recent observation that the use of $\beta$-diketiminato calcium $n$-alkyls enables the unprecedented nucleophilic substitution of a $\mathrm{C}-\mathrm{H}$ bond of benzene (Scheme 1 ). ${ }^{40}$ These reactions produce the $n$-alkyl benzenes through the generation of a calcium hydride such that rupture of the $\mathrm{C}-\mathrm{H}$ bond occurs via an effective $\mathrm{S}_{\mathrm{N}} 2$ displacement of $\mathrm{H}^{-}$. Based on the experimental observation that the alkylation displays half order kinetics, it was proposed that the key step in this transformation was the generation of a monomeric and coordinatively unsaturated calcium alkyl. On this basis, density functional theory (DFT) calculations supported an ensuing mechanism of $\mathrm{C}-\mathrm{H}$ activation which occurs through the assembly of a transition state (IV, Scheme 1) resembling a non-stabilized Meisenheimer complex. We deduced that the nucleophilic attack on the electron rich $\pi$-system was largely facilitated by the high degree of native charge separation between the calcium centre and the organic anion. In this manner, the mechanism of substitution is enabled by both the highly nucleophilic nature of the organic anion and $\eta^{6}$ engagement of the $\pi$-electron density of

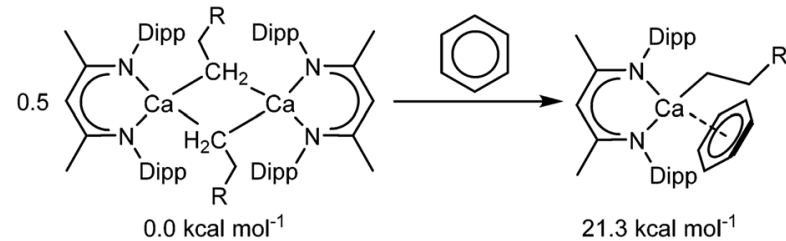

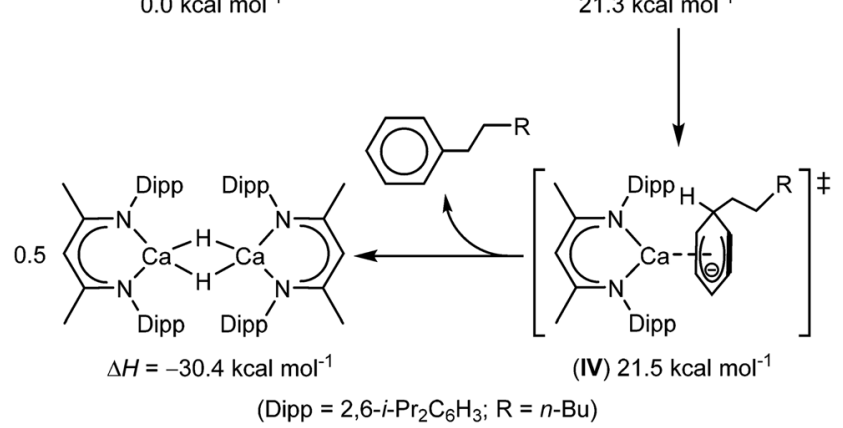

Scheme 1 Calcium-mediated nucleophilic alkylation of benzene.

benzene with the highly electrophilic calcium centre. This cooperative view of the reactivity implies that such Ae- $\pi$-arene interactions may not only provide an influence over structure and (bio)molecular function but also present a means to allow further unprecedented arene-centred transformations. Prior to Harder's very recent contributions, ${ }^{38,39}$ the only previously reported charge separated $\beta$-diketiminato alkaline earth cations are the ion pair systems, $\left[\left({ }^{\mathrm{Me}} \mathrm{BDI}\right) \mathrm{Ae}\left(\mathrm{NC}_{5} \mathrm{H}_{5}\right)_{3}\right]^{+}\left[\mathrm{H}_{2} \mathrm{~N}\{\mathrm{~B}\right.$ $\left.\left.\left(\mathrm{C}_{6} \mathrm{~F}_{5}\right)_{3}\right\}\right]^{-}(\mathrm{Ae}=\mathrm{Ca}, \mathrm{Sr})$, in which the coordination spheres of the electrophilic Ae centres are saturated by the addition of three $\mathrm{N}$-donor pyridines. ${ }^{41}$ In this contribution, therefore, we provide an assessment of the potential of the truly charge separated $\beta$-diketiminato $\mathrm{Mg}$ and $\mathrm{Ca}$ cations to engage with arene $\pi$-systems and soft phosphine donors when generated in conjunction with Krossing's weakly nucleophilic aluminate anion, $\left[\mathrm{Al}\left\{\mathrm{OC}\left(\mathrm{CF}_{3}\right)_{3}\right\}_{4}\right]^{-.42-44}$

\section{Results and discussion}

\section{Arene adducts}

In a manner reminiscent of the recently described behaviour of compounds VI and VII, an initial reaction performed in 
toluene- $d_{8}$ between $\quad[(\mathrm{BDI}) \mathrm{Mg} n-\mathrm{Bu}] \quad(\mathbf{1})$ and $\left[\mathrm{Ph}_{3} \mathrm{C}\right]^{+}[\mathrm{Al}\{\mathrm{OC}$ $\left.\left.\left(\mathrm{CF}_{3}\right)_{3}\right\}_{4}\right]^{-}$resulted in the immediate formation of two immiscible phases. This observation is characteristic of the generation of charge separated metalorganic species and consequent liquid clathrate formation. ${ }^{45,46}$ Although analysis of this mixture by ${ }^{19} \mathrm{~F}\left\{{ }^{1} \mathrm{H}\right\}$ NMR spectroscopy provided a single sharp resonance at $\delta-74.9 \mathrm{ppm}$, in common with many previously reported examples of liquid clathrates, the resultant ${ }^{1} \mathrm{H}$ and ${ }^{13} \mathrm{C}\left\{{ }^{1} \mathrm{H}\right\}$ NMR spectra were broad and largely uninformative. Similar reactions performed between the trityl aluminate and 1 in $\mathrm{C}_{6} \mathrm{D}_{6}$ or with the alternative magnesium organometallic, $\left[\left({ }^{t-\mathrm{Bu}} \mathrm{BDI}\right) \mathrm{Mg} n-\mathrm{Bu}\right](2)$ bearing a more sterically encumbered tert-butyl substituted $\beta$-diketiminate ligand in toluene- $d_{8}$ provided similar observations and the formation of two phase systems. Although clathrate formation hindered definitive solution characterisation by NMR spectroscopy, slow diffusion of hexane into all three reaction solutions at room temperature provided colourless crystals of compounds $\mathbf{3 ,} \mathbf{4}$ and 5 suitable for single crystal X-ray analysis (Scheme 2).

Although isolated samples of compounds 3-5 provided NMR spectra similar to those of the reaction solution when redissolved in either $\mathrm{C}_{6} \mathrm{D}_{6}$ or toluene- $d_{8}$, solution analysis in

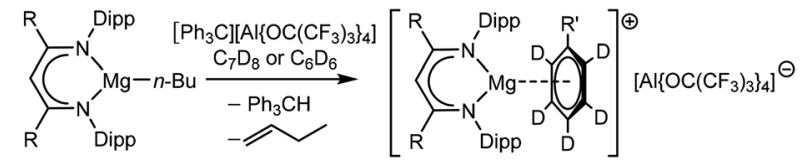

$$
\begin{aligned}
& \text { 1, R }=\mathrm{Me} ; 2, \mathrm{R}=t-\mathrm{Bu} \\
& \text { (Dipp }=2,6-i-\mathrm{Pr}_{2} \mathrm{C}_{6} \mathrm{H}_{3} \text { ) } \\
& 3 \mathrm{R}=\mathrm{Me}, \mathrm{R}^{\prime}=\mathrm{CD}_{3} ; \mathbf{4} \mathrm{R}=\mathrm{Me} \mathrm{R}^{\prime}=\mathrm{D} \\
& 5 \mathrm{R}=t-\mathrm{Bu}, \mathrm{R}^{\prime}=\mathrm{CD}_{3}
\end{aligned}
$$

Scheme 2 Synthesis of compounds 3, 4 and 5.
THF- $\mathrm{d}_{8}$ definitively established the bulk production of the cationic derivatives as their corresponding THF adducts. More significantly, the constitutions of compounds $\mathbf{3}$ and $\mathbf{4}$ in the solid state were identified by single crystal X-ray analysis as the respective toluene- and benzene-adducted magnesium ion pairs $\left[\left({ }^{\mathrm{Me}} \mathrm{BDI}\right) \mathrm{Mg}\left(\mathrm{C}_{6} \mathrm{D}_{5} \mathrm{CD}_{3}\right)\right]^{+}\left[\mathrm{Al}\left\{\mathrm{OC}\left(\mathrm{CF}_{3}\right)_{3}\right\}_{4}\right]^{-}(3)$ and $\left[\left({ }^{\mathrm{Me}} \mathrm{BDI}\right)\right.$ $\left.\mathrm{Mg}\left(\mathrm{C}_{6} \mathrm{D}_{6}\right)\right]^{+}\left[\mathrm{Al}\left\{\mathrm{OC}\left(\mathrm{CF}_{3}\right)_{3}\right\}_{4}\right]^{-}$(4) (Fig. 1). Although single, the crystals of compound $\mathbf{5}$ were very weakly diffracting and the refinement of the structural model was compromised by several factors, all of which contributed to high residuals. Nonetheless, the structural connectivity of $\mathbf{5}$ was unambiguously assigned (Fig. S10†) confirming it as the tolueneadducted magnesium ion pair derivative $\left[\left({ }^{t-\mathrm{Bu}} \mathrm{BDI}\right) \mathrm{Mg}\right.$ $\left.\left(\mathrm{C}_{6} \mathrm{D}_{5} \mathrm{CD}_{3}\right)\right]^{+}\left[\mathrm{Al}\left\{\mathrm{OC}\left(\mathrm{CF}_{3}\right)_{3}\right\}_{4}\right]^{-}$. Hence, the synthesis of compounds 3-5 (Scheme 2) is, strongly reminiscent of that described for both the recently reported compound VI, which was prepared by treatment of $\left[\left({ }^{\mathrm{Me}} \mathrm{BDI}\right) \mathrm{Mgi}-\mathrm{Pr}\right]$ with the trityl salt of $\left[\mathrm{B}\left(\mathrm{C}_{6} \mathrm{~F}_{5}\right)_{4}\right]^{-38}$ and $\left.\left[{ }^{\mathrm{Me}} \mathrm{BDI}\right) \mathrm{Mg}\left\{\mathrm{HB}\left(\mathrm{C}_{6} \mathrm{~F}_{5}\right)_{3}\right\}\right]$, obtained by a similar hydride abstraction reaction of $\left[\left({ }^{\mathrm{Me}} \mathrm{BDI}\right) \mathrm{Mg}\right.$ $\left.\left(\mathrm{NMe}_{2} \mathrm{BH}_{2} \mathrm{NMe}_{2} \mathrm{BH}_{3}\right)\right]$ with $\mathrm{B}\left(\mathrm{C}_{6} \mathrm{~F}_{5}\right)_{3} \cdot{ }^{47,48}$ Significantly, however, the borate anions present in both of these previously reported compounds each bind to the magnesium centres through the above noted $\mathrm{Mg} \cdot \cdots \mathrm{FC}$ interactions or a combination of $\mathrm{B}-\mathrm{H}$ and ortho-C-F coordinative contacts, respectively.

The most notable structural feature of compound 3 is the marginally asymmetric $\eta^{6}$-coordination of the toluene molecule to the magnesium centre. Although a separation of $2.204 \AA$ is observed between the magnesium centre and the centroid defined by the aromatic ring, the presence of the C32bound toluene methyl substituent results in a range of $\mathrm{Mg}-\mathrm{C}$ distances between 2.517(3) (Mg1-C35) and 2.741(3) ̊ (Mg1-C32). In contrast, the magnesium centre of compound 4
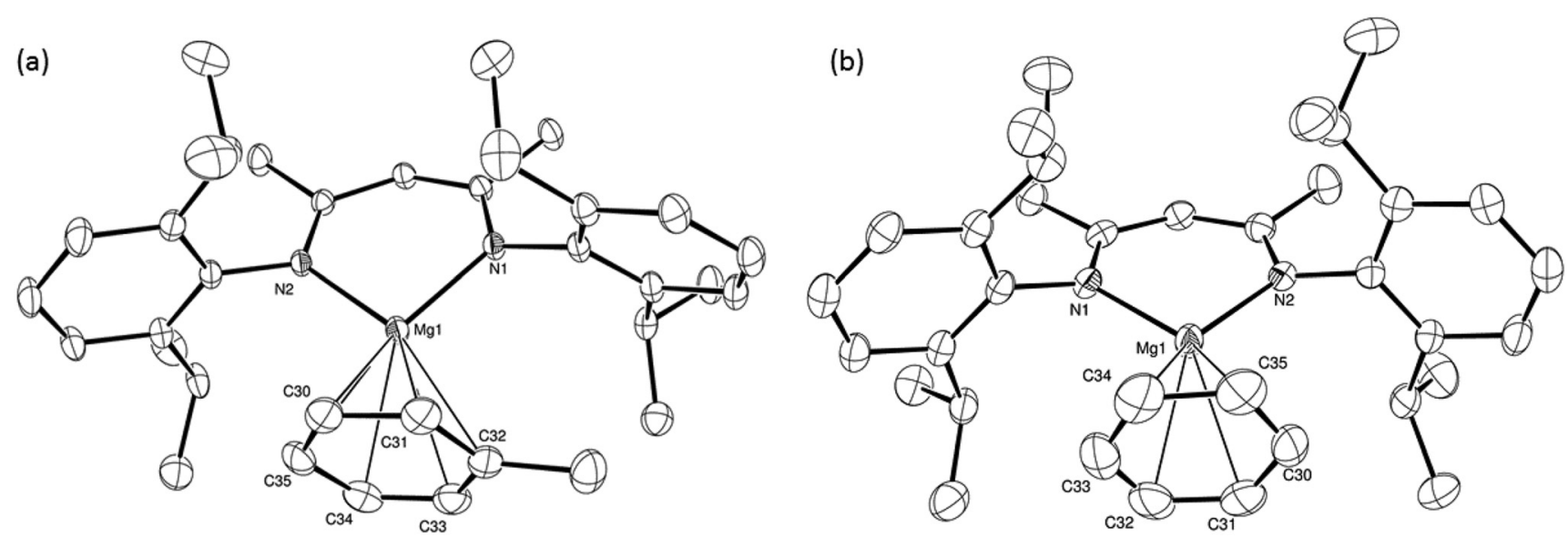

Fig. 1 ORTEP representations of the Mg1-containing cationic components of (a) compound 3 and (b) compound 4 (30\% probability ellipsoids). Hydrogen atoms have been removed for clarity. Selected bond lengths (Å) and angles ( ${ }^{\circ}$ ): (3) Mg1-N1 1.9847(18), Mg1-N2 1.9915(18), Mg1-C30 2.520(3), Mg1-C31 2.607(3), Mg1-C32 2.741(3), Mg1-C33 2.679(3), Mg1-C34 2.574(3), Mg1-C35 2.517(3), C30-Mg1-C31 31.86(10), C30-Mg1-C32 55.13(9), C30-Mg1-C33 64.52(9), C30-Mg1-C34 56.48(10), C31-Mg1-C32 30.09(9), C31-Mg1-C33 53.73(10), C33-Mg1-C32 29.80(10), C34Mg1-C31 64.85(10), C34-Mg1-C32 54.34(10), C34-Mg1-C33 30.60(10), C35-Mg1-C30 31.96(10), C35-Mg1-C31 56.10(10), C35-Mg1-C32 64.35(9), C35-Mg1-C33 54.94(10) C35-Mg1-C34 31.67(10); (4) Mg1-N1 1.981(3), Mg1-N2 1.971(3), Mg1-C30 2.582(5), Mg1-C31 2.541(5), Mg1-C32 2.507(6), Mg1-C33 2.554(5), Mg1-C34 2.593(6), Mg1-C35 2.611(6), C30-Mg1-C34 55.6(2), C30-Mg1-C35 31.1(2), C31-Mg1-C33 54.8(2), C31Mg1-C34 65.0(2), C31-Mg1-C35 55.6(2). 
interacts much more symmetrically with the $\eta^{6}$-bound benzene molecule providing $\mathrm{Mg}-\mathrm{C}$ distances which lie in a narrow range between 2.507(6) (Mg1-C32) and 2.611(6) ^ (Mg1-C35). Although all of these distances are significantly longer than the closest $\mathrm{Mg}-\mathrm{C}$ contact observed in compound VI $(2.367(2) \AA),{ }^{38}$ the arene binding to magnesium in this latter species is significantly perturbed by its interaction with the more coordinating $\left[\mathrm{B}_{(}\left(\mathrm{C}_{6} \mathrm{~F}_{5}\right)_{4}\right]^{-}$anion such that the overall hapticity is lowered to $\eta^{3}$ and with the two other closest $\mathrm{Mg}-\mathrm{C}$ contacts elongated to 2.686(2) and 2.810(2) A. Although all of the $\mathrm{Mg}-\mathrm{C}$ distances observed in compounds $\mathbf{3}$ and $\mathbf{4}$ are significantly longer than typical values ( $c a .1 .95-2.1 \AA)$ calculated for interactions between $\mathrm{Mg}^{2+}$ ions and simple monocyclic arenes, ${ }^{6-11}$ it should be noted that these theoretical results were performed on gas phase dications rather than the monocationic and BDI-supported species described here. Notably, however, the experimentally deduced distances are commensurate with or are shorter than those calculated for the isoelectronic interaction between $\mathrm{C}_{6}$-arenes and either 'naked' $\mathrm{Na}^{+}$or water-adducted sodium monocations. ${ }^{6}$

A further crystallisation of compound 3 performed in the presence of a stoichiometric excess of 1,4-difluorobenzene provided a further new ion paired magnesium complex, compound 6. Although the $\mathrm{Mg} \cdots \mathrm{F}-\mathrm{C}$ interactions were too labile to be observed in solution by NMR spectroscopy, $\mathbf{6}$ was identified by single crystal X-ray analysis as $\left[\left({ }^{\mathrm{Me}} \mathrm{BDI}\right) \mathrm{Mg}\left(1,4-\mathrm{F}_{2} \mathrm{C}_{6} \mathrm{H}_{4}\right)_{3}\right]^{+}[\mathrm{Al}$ $\left.\left\{\mathrm{OC}\left(\mathrm{CF}_{3}\right)_{3}\right\}_{4}\right]^{-}$in which three molecules of 1,4-difluorobenzene interact with the alkaline earth centre via $\kappa^{1}-\mathrm{F}-\mathrm{M}$ interactions (Fig. 2). Similar $\kappa^{1}$ binding of fluorobenzenes is very uncommon and has only been observed previously in a handful of $\mathrm{d}^{0}$ transition metal complexes. ${ }^{49-53}$ 1,4-Difluorobenzene, in particular, is very weakly coordinating and has more typically been observed to interact with metal-centres either through its constituent $\pi$-system ${ }^{54-58}$ or in the unique coordination polymer $\left[\left\{\mathrm{LiN}\left(\mathrm{SiMe}_{3}\right)_{2}\right\}_{2} \cdot 1,4-\mathrm{C}_{6} \mathrm{H}_{4} \mathrm{~F}_{2}\right]_{\infty}$ in which each 1,4difluorobenzene bridges between two dimeric $\left\{\mathrm{LiN}\left(\mathrm{SiMe}_{3}\right)_{2}\right\}_{2}$ units by $\kappa^{1}-\mathrm{Li} \cdots \mathrm{F}$ interactions. ${ }^{59}$ Compound 6 is, thus, unique in providing the first observation of this $\kappa^{1}$ coordination mode for 1,4-difluorobenzene. As expected, the $\mathrm{Mg}-\mathrm{F}$ interactions $[2.029(3)-2.100(3) \AA]$ are significantly longer than those observed in the limited number of molecular magnesium fluorides that have been structurally characterized, for example Parkin's unique terminal fluoride, $\left[\left\{\mathrm{Tp}^{t-\mathrm{Bu}, \mathrm{Me}}\right\} \mathrm{MgF}\right]\left(\mathrm{Tp}^{t-\mathrm{Bu}, \mathrm{Me}}=\right.$ tris(3-tert-butyl-5-pyrazolyl)hydroborate), ${ }^{60}[1.7977(11) \AA]$ and those of the dinuclear complex $\left[\left({ }^{\mathrm{Me}} \mathrm{BDI}\right) \mathrm{Mg}(\mu-\mathrm{F})(\mathrm{THF})\right]_{2}$ [1.951(2) $\AA] .{ }^{61}$ The observation that the Mg-F interactions in 6 are effectively commensurate with those observed in the ion paired species VI [2.046(1) $\mathrm{A}]$ and in several magnesium derivatives of the $\left\{\mathrm{HB}\left(\mathrm{C}_{6} \mathrm{~F}_{5}\right)_{3}\right\}^{-}$anion [ca. 2.08 $\AA$ ] emphasises the highly electrophilic nature of the $\left.\left[{ }^{\mathrm{Me}} \mathrm{BDI}\right) \mathrm{Mg}\right]^{+}$unit. ${ }^{48,62}$

Compound VII was synthesized through reaction of $\left[\left({ }^{\mathrm{Me}} \mathrm{BDI}\right) \mathrm{H}_{2}\right]^{+}\left[\mathrm{B}\left(\mathrm{C}_{6} \mathrm{~F}_{5}\right)_{4}\right]^{-}$and $\left[\mathrm{Ca}(p-t \text {-Bu-benzyl })_{2}\right]$. A further reaction between $\left[\left({ }^{\mathrm{Me}} \mathrm{BDI}\right) \mathrm{CaN}\left(\mathrm{SiMe}_{3}\right)_{2}\right]$ and $\left[\mathrm{Ph}_{3} \mathrm{C}\right]^{+}[\mathrm{Al}\{\mathrm{OC}$ $\left.\left.\left(\mathrm{CF}_{3}\right)_{3}\right\}_{4}\right]^{-}$performed in $\mathrm{C}_{6} \mathrm{D}_{6}$ also provided two immiscible phases, which, after slow diffusion of hexane into the reaction mixture, provided the target calcium cation, compound 7 as a

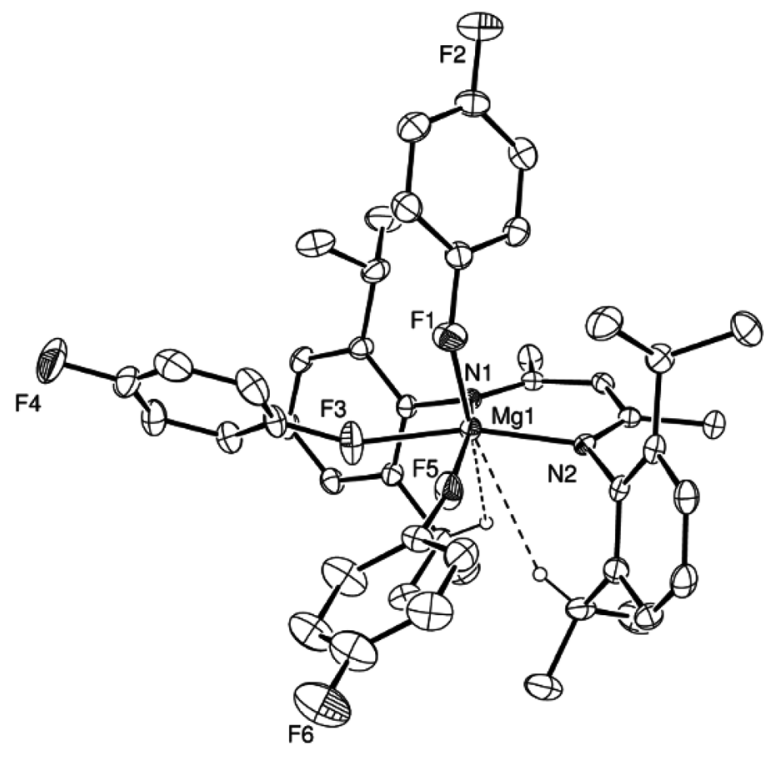

Fig. 2 ORTEP representation of the cationic component of compound 6 (30\% probability ellipsoids). Hydrogen atoms, apart from $\mathrm{H} 15$ and $\mathrm{H} 27$ and the second disordered component of the 1,4-difluorobenzene based on F5 have been omitted for clarity. Selected bond lengths ( $\AA$ ) and angles ( ${ }^{\circ}$ ): Mg1-N1 2.008(3), Mg1-N2 2.015(3), Mg1-F1 2.029(3), Mg1-F3 2.100(3), Mg1-F5 2.073(4), N1-Mg1-N2 96.92(13), N1-Mg1-F5 161.7(3), N2-Mg1-F1 102.94(13), N2-Mg1-F3 164.48(14), N1-Mg1-F1 111.84(13), N1-Mg1-F3 92.40(13), F1-Mg1-F3 84.90(13), F1-Mg1-F5 81.4(3), N2-Mg1-F1 102.94(13), N2-Mg1-F3 164.48(14), N2-Mg1-F5 92.1(3), F5-Mg1-F3 75.7(3).

crop of colourless crystals. After decantation, analysis of the remaining soluble components evidenced the production of a single organic side-product, compound $\mathbf{8}$, which displayed a series of resonances characteristic of phenyl dearomatization in its ${ }^{1} \mathrm{H}$ NMR spectrum. Although compound 7 formally contains the same $\left[\left({ }^{\mathrm{Me}} \mathrm{BDI}\right) \mathrm{Ca}\left(\mathrm{C}_{6} \mathrm{D}_{6}\right)\right]^{+}$cation as compound VII, like the magnesium-benzene adduct (3), the absence of a coordinating anion ensures that the arene $\pi$-system interacts symmetrically with the calcium centre via $\mathrm{Ca}-\mathrm{C}$ interactions of $c a$. $2.93 \AA$ (Fig. 3). These distances are comparable to those observed in VII despite the higher level of charge separation enabled by the use of the less coordinating aluminate anion. Reactions between trityl derivatives of weakly coordinating anions and sterically demanding organophosphines have previously been observed to result in nucleophilic attack at a position para to the central trityl carbon and generation of cylcohexadienyl derivatives. ${ }^{63} \mathrm{~A}$ similar process was inferred to have provided compound $\mathbf{8}$, which was confirmed as the product of bis(trimethylsilyl)amide para-phenyl addition by its independent synthesis through reaction of $\mathrm{KN}\left(\mathrm{SiMe}_{3}\right)_{2}$ and the trityl aluminate. The course of the reaction to provide compounds 7 and 8 was, thus, deduced to proceed as shown in Scheme 3.

Calculations were carried out on compound 7 as well as on the congeneric series of $\left[\left({ }^{\mathrm{Me}} \mathrm{BDI}\right) \mathrm{Ae}\left(\mathrm{C}_{7} \mathrm{H}_{8}\right)\right]^{+}$heavier alkaline earth-toluene cations $(\mathrm{Ae}=\mathrm{Mg}, \mathrm{Ca}, \mathrm{Sr}, \mathrm{Ba})$. The geometries were optimised at the DFT level (B3PW91) including dis- 


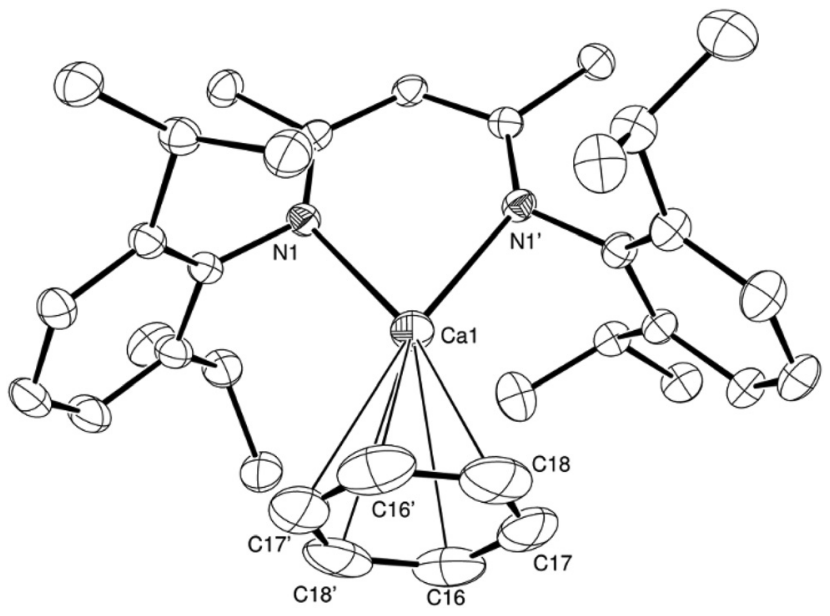

Fig. 3 ORTEP representation of the cationic component of compound 7 ( $30 \%$ probability ellipsoids). Hydrogen atoms have been removed for clarity. Selected bond lengths ( $(\AA)$ and angles ( $\left.{ }^{\circ}\right)$ : Ca1-N1 2.239(3), Ca1C16 2.932(5), Ca1-C17 2.935(5), Ca1-C18 2.932(5), N1'-Ca1-N1 76.26 (14), N1-Ca1-C16 139.39(18), N1'-Ca1-C16 129.46(17), N1-Ca1-C17 166.05(17), N1'-Ca1-C17 114.84(14), N1-Ca1-C18 155.76(18), N1'-Ca1C18 118.74(16). Symmetry operations used to generate equivalent atoms ' $1-x,+y, 1-z$.

persion effects (D3BJ), a methodology which has previously proven its ability to describe subtle interactions in alkaline earth metal complexes. ${ }^{64}$ The optimised geometry of complex 7 (opt. 7) corresponded closely with the experimentally observed structure and provided individual $\mathrm{Ca}-\mathrm{C}$ (benzene) distances of $2.95 \AA$ (versus $\sim 2.93 \AA$ experimentally). This further demonstrates the appropriateness of the computational approach. Analysis of the bonding within opt. 7, indicated that the arene-Ca interaction (HOMO-9) is, primarily, a consequence of significant $\pi$ donation from the aromatic benzene HOMO into an empty $3 \mathrm{~d}$ orbital at the calcium centre (Fig. 4). The consequent disruption to the $\pi$ system can be quantified by analysing the Natural Bonding Orbital (NBO) for the benzene fragment. The total Natural charge of this fragment is +0.13 , indicating a depletion of density that is mainly derived from the $\pi$ system (average occupancy of 1.64e).

A similar study was carried out on the Ae-toluene cations. While the interaction with $\mathrm{Mg}$ was found to be largely electrostatic in origin (Fig. S29a $\uparrow$ ), the HOMO-8 of all three heavier alkaline earth cations, $\left.\left[{ }^{\mathrm{Me}} \mathrm{BDI}\right) \mathrm{Ae}\left(\mathrm{C}_{7} \mathrm{H}_{8}\right)\right]^{+}(\mathrm{Ae}=\mathrm{Ca}, \mathrm{Sr}, \mathrm{Ba})$, exhibited a similar $\pi$-symmetric interaction between the toluene $\pi$-system and a d orbital of the alkaline earth centre

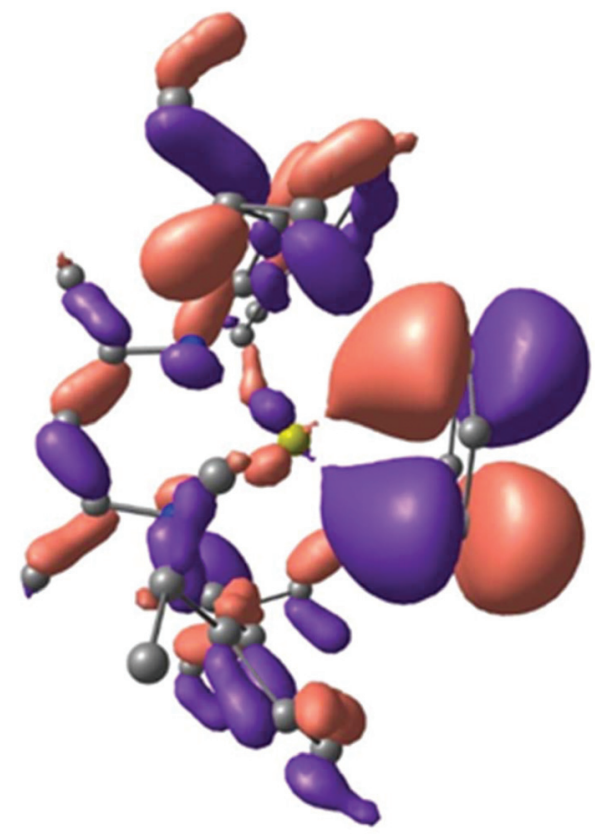

Fig. 4 HOMO-9 molecular orbital of opt. 7 indicating the ligand to metal $\pi$-donation.

(Fig. S29b†). The percentage of the d contribution in this HOMO-8 orbital was found to decrease from $8.5 \%$ (Ca) to $5.3 \%(\mathrm{Sr})$ and $2.9 \%(\mathrm{Ba})$ in line with the expected increase of $\mathrm{d}$ orbital energy from the $3^{\text {rd }}$ to the $5^{\text {th }}$ period, mainly because of relativistic effects. Although the invocation of $(n-1) \mathrm{d}$ orbital participation in the bonding of heavier alkaline earth elements has been somewhat controversial, ${ }^{65}$ their radial maxima have been calculated to lie in the same regions as the outermost core $(n-1)$ p orbitals. ${ }^{66}$ Notably, backbonding interactions from the $5 \mathrm{~d}$ orbitals of barium have also very recently been implicated in the red shifted $\mathrm{CO}$ vibrations which result from co-condensation of laser ablated barium atoms with $\mathrm{CO} / \mathrm{Ne}$ mixtures. ${ }^{67}$ Despite the significant variation in $\mathrm{d}$ orbital participation, $\mathrm{NBO}$ analysis of all three $\left[\left({ }^{\mathrm{Me}} \mathrm{BDI}\right) \mathrm{Ae}\left(\mathrm{C}_{7} \mathrm{H}_{8}\right)\right]^{+}(\mathrm{Ae}=$ $\mathrm{Ca}, \mathrm{Sr}, \mathrm{Ba}$ ) cations indicated that the total Natural charge of the toluene fragment is +0.11 , consistent with minor but potentially significant depletion of $\pi$-electron density. Although these results contrast with those of Harder and coworkers, a different functional was used in the two cases and it may be anticipated that all three heavier alkaline earth centres may be similarly implemented to activate arenes toward otherwise unfavourable nucleophilic attack.



Scheme 3 Synthesis of compounds 7 and 8. 


\section{Phosphine adducts}

Treatment of two-phase solutions of compounds $\mathbf{3}$ and $\mathbf{5}$ in toluene- $d_{8}$ with stoichiometric equivalents of $\mathrm{Ph}_{3} \mathrm{P}$ induced minor but significant downfield shifts in the resultant ${ }^{31} \mathrm{P}\left\{{ }^{1} \mathrm{H}\right\}$ NMR spectra in comparison to the resonant frequency of the pure phosphine $(\delta-5.30 \mathrm{ppm})$. This solution-based evidence for the generation of the respective magnesium phosphine coordination complexes $9(\delta-4.94 \mathrm{ppm})$ and $10(\delta-4.61 \mathrm{ppm})$ (Scheme 4) was confirmed by the isolation of colourless crystals of both compounds by slow diffusion of hexane into the reaction mixtures. The results of the respective single crystal X-ray diffraction analyses are shown in Fig. 5a and b and establish that the monodentate phosphine coordinates in a terminal fashion to the magnesium centres in both complexes.

The magnesium centres of both compounds $\mathbf{9}$ and $\mathbf{1 0}$ are effectively co-planar with the delocalised $\beta$-diketiminate ligands, lying only 0.064 and $0.078 \AA$ out of the respective least squares planes defined by the $\mathrm{C}_{3} \mathrm{~N}_{2}$ chelate. Replacement of the methyl groups of the supporting ligand of $\mathbf{9}$ by the bulkier tert-butyl substituents of $\mathbf{1 0}$ induces only minor adjustments to the distorted trigonal planar magnesium coordination geometry. The consequently increased steric constraints imposed on the coordination environment of $\mathbf{1 0}$, however, are reflected in a significant elongation of the $\mathrm{Mg}-\mathrm{P}$ distance from 2.5972(13) A to 2.6805(12) A. Consistent with the formal positive charges and the lower coordination numbers of the magnesium cations, however, both of these bond lengths are notably shorter than those observed in compounds IV [2.770(1), 2.761(1) $\AA]^{36}$ and $\mathbf{V}[2.65(1), 2.66(1) \AA]^{37}$ and are more typical of the $\mathrm{Mg}-\mathrm{P}$ separations reported for terminal primary and secondary magnesium phosphide derivatives such as $\left[\mathrm{Mg}(\mathrm{PHPh})_{2}(\mathrm{TMEDA})\right][2.592(5), 2.587(5) \AA]^{25}$ and $\left[\left({ }^{\mathrm{Me}} \mathrm{BDI}\right)\right.$ $\left.\mathrm{MgPPh}_{2}(\mathrm{THF})\right][2.531(3) \AA],{ }^{35}$ the latter of which comprises the identical $\beta$-diketiminate ligand as that employed in the synthesis of compound 9.

Density functional theory (DFT) calculations (B3PW91) were carried out to assess the nature of the $\mathrm{Mg}-\mathrm{P}$ interaction of compound 10. The optimised geometry of opt. 10 accurately replicates experimentally observed structure, providing a $\mathrm{Mg}-\mathrm{P}$ distance of $2.65 \AA$ A. Analysis of the magnesium to phosphorus bonding (HOMO-5, Fig. 6) indicated that the interaction may



Scheme 4 Synthesis of compounds 9 and 10.

(a)

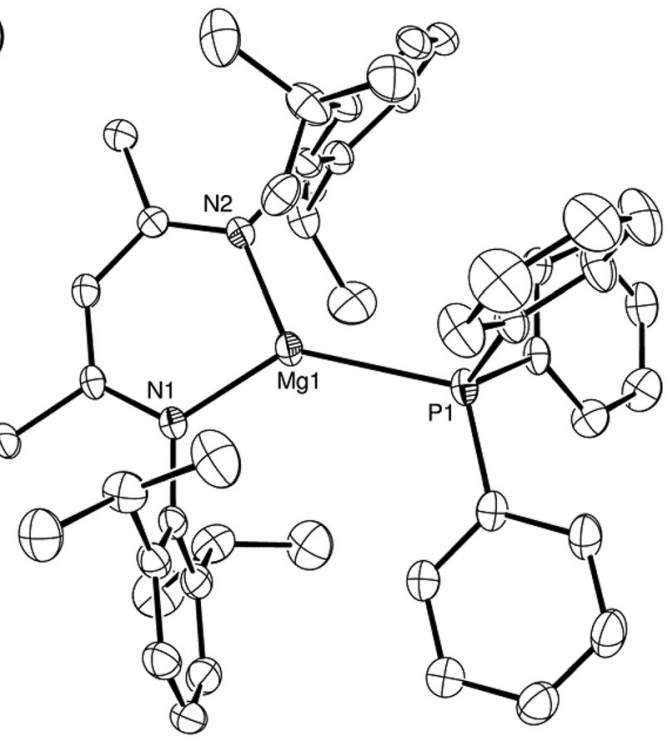



Fig. 5 ORTEP representations ( $25 \%$ probability ellipsoids) of the cationic components in (a) compound 9 and (b) compound 10 . Hydrogen atoms throughout, plus the minor disordered components of the carbon atoms in the $\mathrm{PPh}_{3}$ ligand of compound 9 are omitted for clarity. Selected bond lengths (Å) and angles ('): 9: P1-Mg1 2.5972(13), Mg1-N1 1.977(3), Mg1-N2 1.983(3), N1-Mg1-P1 134.47(10), N2-Mg1-P1 127.44(9), N1-Mg1-N2 97.51(12); 10: P1-Mg1 2.6805(12), Mg1-N1 1.989(2), Mg1-N2 1.988(2), N1-Mg1-P1 130.37(8), N2-Mg1-P1 130.96(7), N2-Mg1-N1 98.25(10). 


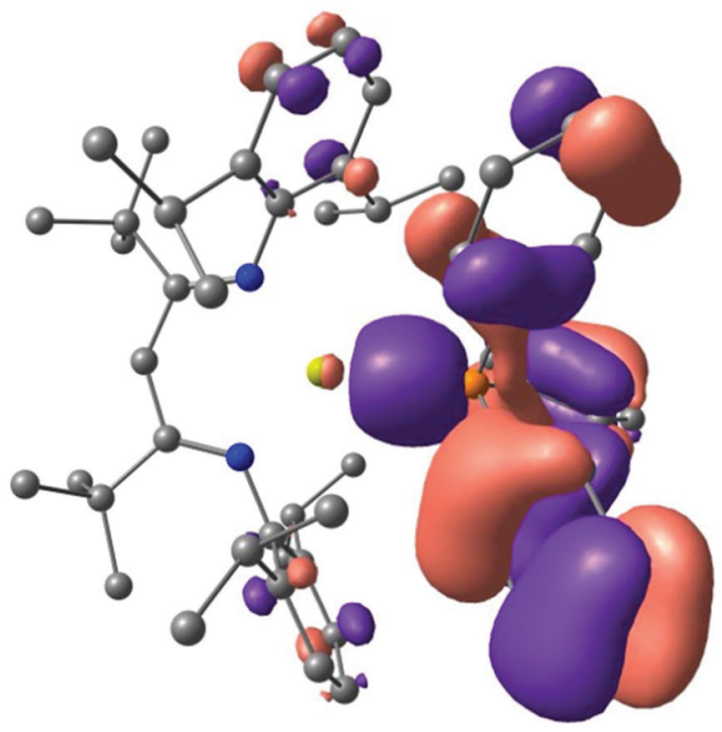

Fig. 6 HOMO-5 molecular orbital of opt. 10 highlighting the polarisation of the phosphine lone pair electron density to magnesium.

be considered as largely electrostatic in origin through what is an effective polarisation of the phosphine lone pair to the $\left[\left({ }^{t-\mathrm{Bu}} \mathrm{BDI}\right) \mathrm{Mg}\right]^{+}$cation.

\section{Conclusions}

In conclusion, we have shown that generation of $\beta$-diketiminato magnesium and calcium cations in conjunction with the weakly coordinating $\left[\mathrm{Al}\left\{\mathrm{OC}\left(\mathrm{CF}_{3}\right)_{3}\right\}_{4}\right]^{-}$anion in benzene or toluene, allows the isolation of completely charge separated $\eta^{6}$ adducts in which the polyhapto coordination of the arene ligand is unperturbed by any interaction with the anion. DFT calculations implicate minor but potentially significant $3 \mathrm{~d}$ orbital participation in the binding to calcium. The magnesium cations react with $\mathrm{PPh}_{3}$ to allow the isolation of the first molecular species in which magnesium is coordinated by a monodentate phosphine base. While the Mg-P binding is effectively electrostatic, it has not escaped our attention that the combination of the hard electrophilic magnesium cations of compounds 9 and 10 with the softer basic $\mathrm{PPh}_{3}$ is reminiscent of the combinations of $\mathrm{p}$-block derivatives that can give rise to so-called 'frustrated' Lewis pair reactivity with small molecule substrates. We are, thus, continuing investigate the implications of these observations and to explore the properties of these outwardly simple highly electrophilic molecules.

\section{Experimental section}

All manipulations were carried out using standard Schlenk line and glovebox techniques under an inert atmosphere of argon. NMR experiments were conducted in J. Young tap NMR tubes made up and sealed in a Glovebox. NMR spectra were collected at $298 \mathrm{~K}$ on an Agilent ProPulse spectrometer operating at $500 \mathrm{MHz}\left({ }^{1} \mathrm{H}\right), 126 \mathrm{MHz}\left({ }^{13} \mathrm{C}\right), 125.8 \mathrm{MHz}\left({ }^{31} \mathrm{P}\right)$ and $470 \mathrm{MHz}\left({ }^{19} \mathrm{~F}\right)$ and referenced relative to residual solvent resonances. Microanalysis were performed by $\mathrm{Mr} \mathrm{S}$. Boyer of London Metropolitan Enterprises. $\mathrm{C}_{6} \mathrm{D}_{6}$, tol- $d_{8}$ and THF- $d_{8}$ were purchased from Fluorochem Ltd and Sigma-Aldrich Ltd and dried over molten potassium before distilling under argon and storing over molecular sieves in the glovebox. 1,4-Difluorobenzene and triphenylphosphine $\left(\mathrm{PPh}_{3}\right)$ were purchased from Sigma-Aldrich Ltd and triphenylcarbenium tetrakis(perfluoro-tert-butoxy)aluminate $\left(\left[\mathrm{Ph}_{3} \mathrm{C}\right]\left[\mathrm{Al}\left(\mathrm{OC}\left(\mathrm{CF}_{3}\right)_{3}\right)_{4}\right]\right)$ from Ionic Liquids Technologies $\mathrm{GmbH}$ and used without further purification. $\left[\left({ }^{\mathrm{Me}} \mathrm{BDI}\right) \mathrm{Mg}^{n} \mathrm{Bu}\right],\left[\left({ }^{t-\mathrm{Bu}} \mathrm{BDI}\right) \mathrm{Mg}^{n} \mathrm{Bu}\right]$ and $\left[\left({ }^{\mathrm{Me}} \mathrm{BDI}\right) \mathrm{CaN}\left(\mathrm{SiMe}_{3}\right)_{2}\right]\left({ }^{\mathrm{Me}} \mathrm{BDI}=\operatorname{HC}\{(\mathrm{Me}) \mathrm{CN}(\mathrm{Dipp})\}_{2},{ }^{t-\mathrm{Bu}} \mathrm{BDI}=\right.$ $\mathrm{HC}\left\{\left({ }^{t} \mathrm{Bu}\right) \mathrm{CN}(\mathrm{Dipp})\right\}_{2}$, Dipp $\left.=2,6-{ }^{\mathrm{i}} \mathrm{Pr}_{2} \mathrm{C}_{6} \mathrm{H}_{3}\right)$ were synthesised by literature procedures. ${ }^{68-70}$

\section{Synthesis of $\left[\left({ }^{\mathrm{Me}} \mathrm{BDI}\right) \mathrm{Mg}\left(\mathrm{C}_{6} \mathrm{D}_{5} \mathrm{CD}_{3}\right)\right]\left[\mathrm{Al}\left(\mathrm{OC}\left(\mathrm{CF}_{3}\right)_{3}\right)_{4}\right](3)$}

$\left[\left({ }^{\mathrm{Me}} \mathrm{BDI}\right) \mathrm{Mg}^{n} \mathrm{Bu}\right](30 \mathrm{mg}, 0.060 \mathrm{mmol})$ and $\left[\mathrm{Ph}_{3} \mathrm{C}\right][\mathrm{Al}(\mathrm{OC}$ $\left.\left.\left(\mathrm{CF}_{3}\right)_{3}\right)_{4}\right]$ (73 mg, $\left.0.060 \mathrm{mmol}\right)$ were dissolved in toluene- $d_{8}$ $(0.5 \mathrm{~mL})$ in a sealed J. Young NMR tube, with the appearance of two immiscible phases which were left overnight at room temperature. Colourless crystals of 3 suitable for X-ray analysis were formed by slow diffusion of hexane into the reaction mixture. Yield: $78 \mathrm{mg}, 90 \%$. ${ }^{1} \mathrm{H}$ NMR (500 MHz, tol- $d_{8}, 298 \mathrm{~K}$ ): Isomer A (50\%): $\delta$ 7.15-6.93 (6H, CH Dipp), 4.55 (s broad, 1H, $\mathrm{CH}\{\mathrm{C}(\mathrm{Me}) \mathrm{NDipp}\}_{2}$ ), 2.21 (hept broad, ${ }^{3} J_{\mathrm{HH}}=6.4 \mathrm{~Hz}, 4 \mathrm{H}$, $\left.\mathrm{CH}\left(\mathrm{CH}_{3}\right)_{2}\right), 1.09$ (s broad, 6H, $\left.\mathrm{CH}\left\{\mathrm{C}\left(\mathrm{CH}_{3}\right) \mathrm{NDipp}\right\}_{2}\right), 1.01$ (d broad, $\left.{ }^{3} J_{\mathrm{HH}}=6.2 \mathrm{~Hz}, 12 \mathrm{H}, \mathrm{CH}\left(\mathrm{CH}_{3}\right)_{2}\right), 0.85 \mathrm{ppm}$ (d broad, $\left.{ }^{3} J_{\mathrm{HH}}=5.9 \mathrm{~Hz}, 12 \mathrm{H}, \mathrm{CH}\left(\mathrm{CH}_{3}\right)_{2}\right)$; Isomer B (50\%): $\delta 7.37-6.71$ (6H, CH Dipp), 4.55 (s, 1H, CH\{C(Me)NDipp $\}_{2}$ ), 2.27 (hept, $\left.{ }^{3} J_{\mathrm{HH}}=6.9 \mathrm{~Hz}, 4 \mathrm{H}, \mathrm{CH}\left(\mathrm{CH}_{3}\right)_{2}\right), 1.31\left(\mathrm{~s}, 6 \mathrm{H}, \mathrm{CH}\left\{\mathrm{C}\left(\mathrm{CH}_{3}\right) \mathrm{NDipp}\right\}_{2}\right)$, $1.08\left(\mathrm{~d},{ }^{3} J_{\mathrm{HH}}=6.9 \mathrm{~Hz}, 12 \mathrm{H}, \mathrm{CH}\left(\mathrm{CH}_{3}\right)_{2}\right), 0.89 \mathrm{ppm}\left(\mathrm{d},{ }^{3} J_{\mathrm{HH}}=\right.$ $\left.6.7 \mathrm{~Hz}, 12 \mathrm{H}, \mathrm{CH}\left(\mathrm{CH}_{3}\right)_{2}\right) .{ }^{19} \mathrm{~F}\left\{{ }^{1} \mathrm{H}\right\}$ NMR $\left(470 \mathrm{MHz}\right.$, tol- $\left.d_{8}, 298 \mathrm{~K}\right)$ : Isomer A (50\%): $\delta$-75.09 ppm (s); Isomer B (50\%): $\delta-74.90 \mathrm{ppm}(\mathrm{s})$. Elemental analysis (\%). Found: C 37.83, $\mathrm{H}$ 3.20, $\mathrm{N}$ 2.21. Calculated for $\mathrm{C}_{45} \mathrm{H}_{41} \mathrm{AlF}_{36} \mathrm{O}_{4} \mathrm{MgN}_{2}$ ([( $\left.{ }^{\mathrm{Me}} \mathrm{BDI}\right)$ $\left.\mathrm{Mg}]\left[\mathrm{Al}\left(\mathrm{OC}\left(\mathrm{CF}_{3}\right)_{3}\right)_{4}\right]\right): \mathrm{C} 38.36, \mathrm{H} 2.93, \mathrm{~N} 1.99$.

\section{Synthesis of $\left[\left({ }^{\mathrm{Me}} \mathrm{BDI}\right) \mathrm{Mg}\left(\mathrm{C}_{4} \mathrm{D}_{8} \mathrm{O}\right)\right]\left[\mathrm{Al}\left(\mathrm{OC}\left(\mathrm{CF}_{3}\right)_{3}\right)_{4}\right](3 \cdot \mathrm{THF})$}

$\left[\left({ }^{\mathrm{Me}} \mathrm{BDI}\right) \mathrm{Mg}\left(\mathrm{C}_{6} \mathrm{D}_{5} \mathrm{CD}_{3}\right)\right]\left[\mathrm{Al}\left(\mathrm{OC}\left(\mathrm{CF}_{3}\right)_{3}\right)_{4}\right](30 \mathrm{mg}, 0.020 \mathrm{mmol})$ was dissolved in THF- $d_{8}(0.5 \mathrm{~mL})$ in a sealed J. Young NMR tube. The solvent was evaporated to dryness and the residue washed with hexane $(3 \times 5 \mathrm{~mL})$ to afford a pale yellow solid. Yield: $29 \mathrm{mg}, 98 \% .{ }^{1} \mathrm{H}$ NMR (500 MHz, THF- $\left.d_{8}, 298 \mathrm{~K}\right): \delta 7.29-7.05$ (6H, CH Dipp), 5.16 (s, 1H, CH\{C(Me)NDipp $\left.\}_{2}\right), 3.05$ (hept, $\left.{ }^{3} J_{\mathrm{HH}}=6.9 \mathrm{~Hz}, 4 \mathrm{H}, \mathrm{CH}\left(\mathrm{CH}_{3}\right)_{2}\right), 1.82\left(\mathrm{~s}, 6 \mathrm{H}, \mathrm{CH}\left\{\mathrm{C}\left(\mathrm{CH}_{3}\right) \mathrm{NDipp}\right\}_{2}\right)$, $1.24 \mathrm{ppm}\left(\mathrm{d},{ }^{3} \mathrm{~J}_{\mathrm{HH}}=6.9 \mathrm{~Hz}, 24 \mathrm{H}, \mathrm{CH}\left(\mathrm{CH}_{3}\right)_{2}\right) .{ }^{13} \mathrm{C}\left\{{ }^{1} \mathrm{H}\right\} \mathrm{NMR}$ (126 MHz, THF- $\left.d_{8}, 298 \mathrm{~K}\right): \delta 172.7$ (s, NC(Me)), $144.0\left(\mathrm{~s}, C-{ }^{\mathrm{i}} \mathrm{Pr}\right.$ ), 143.0 (s, N-C Dipp), 127.3 (s, p-CH Dipp), 125.2 (s, $m-\mathrm{CH}$ Dipp), 123.6 (s, p-CH Dipp), 96.0 (s, $\left.C H\{\mathrm{C}(\mathrm{Me}) \mathrm{NDipp}\}_{2}\right), 29.3$ (s, $\mathrm{CH}\left(\mathrm{CH}_{3}\right)_{2}$ ), 25.2 (s, $\mathrm{CH}_{3}$ Dipp), 24.6 (s, $\mathrm{CH}_{3}$ Dipp), 24.5 ppm (s, CH-CH $\mathrm{H}_{3}$ Dipp). ${ }^{19} \mathrm{~F}\left\{{ }^{1} \mathrm{H}\right\}$ NMR (470 MHz, THF- $d_{8}, 298 \mathrm{~K}$ ): $\delta-74.03 \mathrm{ppm}(\mathrm{s})$. Elemental analysis (\%). Found: C 39.32, $\mathrm{H}$ 3.37, N 1.98. Calculated for $\mathrm{C}_{49} \mathrm{H}_{49} \mathrm{AlF}_{36} \mathrm{O}_{5} \mathrm{MgN}_{2}$ : C 39.73, H 3.33, N 1.89 . 


\section{Synthesis of $\left[\left({ }^{\mathrm{Me}} \mathrm{BDI}\right) \mathrm{Mg}\left(\mathrm{C}_{6} \mathrm{D}_{6}\right)\right]\left[\mathrm{Al}\left(\mathrm{OC}\left(\mathrm{CF}_{3}\right)_{3}\right)_{4}\right](4)$}

$\left[\left({ }^{\mathrm{Me}} \mathrm{BDI}\right) \mathrm{Mg}^{n} \mathrm{Bu}\right](30 \mathrm{mg}, 0.060 \mathrm{mmol})$ and $\left[\mathrm{Ph}_{3} \mathrm{C}\right][\mathrm{Al}(\mathrm{OC}$ $\left.\left.\left(\mathrm{CF}_{3}\right)_{3}\right)_{4}\right](73 \mathrm{mg}, 0.060 \mathrm{mmol})$ were dissolved in $\mathrm{C}_{6} \mathrm{D}_{6}(0.5 \mathrm{~mL})$ in a sealed J. Young NMR tube, with the appearance of two immiscible phases which were left overnight at room temperature. Colourless crystals of $\mathbf{4}$ suitable for X-ray analysis were formed by slow diffusion of hexane into the reaction mixture. Yield: $81 \mathrm{mg}, 91 \% .{ }^{1} \mathrm{H}$ NMR (500 MHz, $\left.\mathrm{C}_{6} \mathrm{D}_{6}, 298 \mathrm{~K}\right)$ : Isomer A (70\%): $\delta$ 7.37-6.71 (6H, CH Dipp), 4.55 (s, 1H, CH\{C(Me) NDipp $\left.\}_{2}\right), 2.17$ (hept, $\left.{ }^{3} J_{\mathrm{HH}}=7.4 \mathrm{~Hz}, 4 \mathrm{H}, \mathrm{CH}\left(\mathrm{CH}_{3}\right)_{2}\right), 1.29(\mathrm{~s}, 6 \mathrm{H}$, $\left.\mathrm{CH}\left\{\mathrm{C}\left(\mathrm{CH}_{3}\right) \mathrm{NDipp}\right\}_{2}\right), 0.98\left(\mathrm{~d},{ }^{3} J_{\mathrm{HH}}=6.3 \mathrm{~Hz}, 12 \mathrm{H}, \mathrm{CH}\left(\mathrm{CH}_{3}\right)_{2}\right)$, $0.84 \mathrm{ppm}\left(\mathrm{d},{ }^{3} \mathrm{~J}_{\mathrm{HH}}=6.4 \mathrm{~Hz}, 12 \mathrm{H}, \mathrm{CH}\left(\mathrm{CH}_{3}\right)_{2}\right)$; Isomer B $(30 \%)$ : $\delta$ 7.37-6.71 (6H, CH Dip), 4.53 (broad, $1 \mathrm{H}, \mathrm{CH}\{\mathrm{C}(\mathrm{Me}) \mathrm{NDipp}\}_{2}$ ), 2.24 (broad, $\left.4 \mathrm{H}, \mathrm{CH}\left(\mathrm{CH}_{3}\right)_{2}\right), 1.29-1.27$ (broad, $6 \mathrm{H}, \mathrm{CH}\left\{\mathrm{C}\left(\mathrm{CH}_{3}\right)\right.$ NDipp $\}_{2}$ ), 1.07-1.03 (broad, $\left.12 \mathrm{H}, \mathrm{CH}\left(\mathrm{CH}_{3}\right)_{2}\right), 0.89-0.86 \mathrm{ppm}$ (broad, $\left.12 \mathrm{H}, \mathrm{CH}\left(\mathrm{CH}_{3}\right)_{2}\right) .{ }^{19} \mathrm{~F}\left\{{ }^{1} \mathrm{H}\right\}$ NMR $\left(470 \mathrm{MHz}, \mathrm{C}_{6} \mathrm{D}_{6}, 298 \mathrm{~K}\right)$ : Isomer A (70\%): $\delta$-74.83 ppm (s); Isomer B (30\%): $\delta-75.08 \mathrm{ppm}(\mathrm{s})$. Elemental analysis (\%). Found: C 37.93, $\mathrm{H} 3.10, \mathrm{~N}$ 2.11. Calculated for $\mathrm{C}_{45} \mathrm{H}_{41} \mathrm{AlF}_{36} \mathrm{O}_{4} \mathrm{MgN}_{2}\left(\left[\left({ }^{\mathrm{Me}} \mathrm{BDI}\right)\right.\right.$ $\left.\mathrm{Mg}]\left[\mathrm{Al}\left(\mathrm{OC}\left(\mathrm{CF}_{3}\right)_{3}\right)_{4}\right]\right): \mathrm{C} 38.36, \mathrm{H} 2.93, \mathrm{~N} 1.99$.

\section{Synthesis of $\left.\left[{ }^{-\mathrm{Bu}} \mathrm{BDI}\right) \mathrm{Mg}\left(\mathrm{C}_{6} \mathrm{D}_{5} \mathrm{CD}_{3}\right)\right]\left[\mathrm{Al}\left(\mathrm{OC}\left(\mathrm{CF}_{3}\right)_{3}\right)_{4}\right](5)$}

$\left[\left({ }^{(-\mathrm{Bu}} \mathrm{BDI}\right) \mathrm{Mg}^{n} \mathrm{Bu}\right](30 \mathrm{mg}, 0.051 \mathrm{mmol})$ and $\left[\mathrm{Ph}_{3} \mathrm{C}\right][\mathrm{Al}(\mathrm{OC}$ $\left.\left.\left(\mathrm{CF}_{3}\right)_{3}\right)_{4}\right]$ (62 mg, $\left.0.051 \mathrm{mmol}\right)$ were dissolved in toluene- $d_{8}$ $(0.5 \mathrm{~mL})$ in a sealed J. Young NMR tube, with the appearance of two immiscible phases that were left overnight at room temperature. Storage of this mixture at room temperature with a third layer of hexane yielded colourless crystals of 5 suitable for crystallographic analysis. Yield: $65 \mathrm{mg}, 80 \% .{ }^{1} \mathrm{H}$ NMR (500 MHz, $\mathrm{C}_{6} \mathrm{D}_{6}, 298 \mathrm{~K}$ ): $\delta 7.05$ (6H, CH Dipp), 5.19 (s, $1 \mathrm{H}, \mathrm{CH}$ $\left.\left\{\mathrm{C}\left({ }^{t} \mathrm{Bu}\right) \mathrm{NDipp}\right\}_{2}\right), 3.30$ (hept, $\left.{ }^{3} J_{\mathrm{HH}}=6.9 \mathrm{~Hz}, 4 \mathrm{H}, \mathrm{CH}\left(\mathrm{CH}_{3}\right)_{2}\right), 1.32$ $\left(\mathrm{d},{ }^{3} \mathrm{~J}_{\mathrm{HH}}=5.1 \mathrm{~Hz}, 30 \mathrm{H}, \mathrm{CH}\left(\mathrm{CH}_{3}\right)_{2}\right.$ and $\left.\mathrm{C}-\mathrm{CH}_{3}\right), 0.96 \mathrm{ppm}(\mathrm{d}$, $\left.{ }^{3} J_{\mathrm{HH}}=6.8 \mathrm{~Hz}, 12 \mathrm{H}, \mathrm{CH}\left(\mathrm{CH}_{3}\right)_{2}\right) \cdot{ }^{19} \mathrm{~F}\left\{{ }^{1} \mathrm{H}\right\}$ NMR $\left(470 \mathrm{MHz}\right.$, tol- $d_{8}$, $298 \mathrm{~K}$ ): $\delta-74.17 \mathrm{ppm}(\mathrm{s})$. Elemental analysis (\%). Found: C 44.61, $\mathrm{H}$ 4.08, N 1.76. Calculated for $\mathrm{C}_{58} \mathrm{H}_{61} \mathrm{AlF}_{36} \mathrm{O}_{4} \mathrm{MgN}_{2}$ : C 43.94, H 3.88, N 1.77 .

\section{Synthesis of $\left[\left({ }^{t-\mathrm{Bu}} \mathrm{BDI}\right) \mathrm{Mg}\left(\mathrm{C}_{4} \mathrm{D}_{8} \mathrm{O}\right)\right]\left[\mathrm{Al}\left(\mathrm{OC}\left(\mathrm{CF}_{3}\right)_{3}\right)_{4}\right](5 \cdot \mathrm{THF})$}

In a sealed J. Young NMR tube, $\left.\left[{ }^{t-\mathrm{Bu}} \mathrm{BDI}\right) \mathrm{Mg}\left(\mathrm{C}_{6} \mathrm{D}_{5} \mathrm{CD}_{3}\right)\right][\mathrm{Al}(\mathrm{OC}$ $\left.\left.\left(\mathrm{CF}_{3}\right)_{3}\right)_{4}\right]$ (30 mg, $\left.0.019 \mathrm{mmol}\right)$ was dissolved in THF- $d_{8}$ $(0.5 \mathrm{~mL})$. The solvent was evaporated to dryness and the residue washed with hexane $(3 \times 5 \mathrm{~mL})$ to afford a pale yellow solid. Yield: $28 \mathrm{mg}, 96 \% .{ }^{1} \mathrm{H}$ NMR $\left(500 \mathrm{MHz}\right.$, THF- $\left.d_{8}, 298 \mathrm{~K}\right): \delta$ 7.22-7.16 (5H, $m, p$-CH Dipp), $7.06\left(\mathrm{t},{ }^{3} \mathrm{~J}_{\mathrm{HH}}=7.8 \mathrm{~Hz}, 1 \mathrm{H}, p-\mathrm{CH}\right.$ Dipp), $5.65\left(\mathrm{~s}, 1 \mathrm{H}, \mathrm{CH}\left\{\mathrm{C}\left({ }^{t} \mathrm{Bu}\right) \mathrm{NDipp}\right\}_{2}\right), 3.12\left(\right.$ hept,${ }^{3} J_{\mathrm{HH}}=6.8 \mathrm{~Hz}$, $\left.4 \mathrm{H}, \mathrm{CH}\left(\mathrm{CH}_{3}\right)_{2}\right), 1.39\left(\mathrm{~d},{ }^{3} \mathrm{JHH}_{\mathrm{HH}}=6.7 \mathrm{~Hz}, 12 \mathrm{H}, \mathrm{CH}\left(\mathrm{CH}_{3}\right)_{2}\right), 1.23(\mathrm{~d}$, $\left.{ }^{3} J_{\mathrm{HH}}=6.9 \mathrm{~Hz}, 12 \mathrm{H}, \mathrm{CH}\left(\mathrm{CH}_{3}\right)_{2}\right), 1.21 \mathrm{ppm}\left(\mathrm{s}, 18 \mathrm{H}, \mathrm{C}-\mathrm{CH}_{3}\right)$. ${ }^{13} \mathrm{C}\left\{{ }^{1} \mathrm{H}\right\}$ NMR (126 MHz, THF- $\left.d_{8}, 298 \mathrm{~K}\right): \delta 181.5$ (s, NC( $\left.{ }^{t} \mathrm{Bu}\right)$ ), 145.4 (s, N-C Dipp), 142.5 (s, $C-{ }^{\mathrm{i}} \mathrm{Pr}$ ), 126.8 (s, $p$-CH Dipp), 125.4 (s, $m$-CH Dipp), 123.4 (s, $p$-CH Dipp), 97.4 (s, $C \mathrm{H}\left\{\mathrm{C}\left({ }^{t} \mathrm{Bu}\right)\right.$ NDipp $\left.\}_{2}\right), 45.7$ (s, $\left.C{ }^{t} \mathrm{Bu}\right), 33.3\left(\mathrm{~s}, \mathrm{CH}_{3}{ }^{t} \mathrm{Bu}\right), 29.1\left(\mathrm{~s}, \mathrm{CH}\left(\mathrm{CH}_{3}\right)_{2}\right)$, 26.6 (s, $\mathrm{CH}_{3}$ Dipp), $24.7 \mathrm{ppm}$ (s, $\mathrm{CH}_{3}$ Dipp). ${ }^{19} \mathrm{~F}\left\{{ }^{1} \mathrm{H}\right\}$ NMR $\left(470 \mathrm{MHz}, \mathrm{THF}-d_{8}, 298 \mathrm{~K}\right): \delta-79.98 \mathrm{ppm}(\mathrm{s})$. Elemental analysis (\%). Found: C 42.11, H 4.03, N 1.76. Calculated for $\mathrm{C}_{55} \mathrm{H}_{61} \mathrm{AlF}_{36} \mathrm{O}_{5} \mathrm{MgN}_{2}$ : C 42.20, H 3.93, N 1.79.

\section{Synthesis of $\left[\left({ }^{\mathrm{Me}} \mathrm{BDI}\right) \mathrm{Mg}\left(\mathrm{C}_{6} \mathbf{D}_{4} \mathrm{~F}_{2}\right)_{3}\right]\left[\mathrm{Al}\left(\mathrm{OC}\left(\mathrm{CF}_{3}\right)_{3}\right)_{4}\right](6)$}

$\left[\left({ }^{\mathrm{Me}} \mathrm{BDI}\right) \mathrm{Mg}^{n} \mathrm{Bu}\right](30 \mathrm{mg}, \quad 0.060 \mathrm{mmol})$ and $\left[\mathrm{Ph}_{3} \mathrm{C}\right][\mathrm{Al}(\mathrm{OC}$ $\left.\left.\left(\mathrm{CF}_{3}\right)_{3}\right)_{4}\right](73 \mathrm{mg}, 0.060 \mathrm{mmol})$ were dissolved in 1,4-difluorobenzene $(0.5 \mathrm{~mL})$ with the appearance of two immiscible phases and the resulting mixture vigourously stirred for one minute and left overnight at room temperature. Colourless crystals of 6 suitable for X-ray crystallography were grown by slow diffusion of hexane into the reaction mixture. Yield: $94 \mathrm{mg}, 89 \% .{ }^{19} \mathrm{~F}\left\{{ }^{1} \mathrm{H}\right\}$ NMR $\left(470 \mathrm{MHz}, \mathrm{C}_{6} \mathrm{D}_{6}, 298 \mathrm{~K}\right): \delta-74.85$ (s), 119.58 (q) ppm. Elemental analysis (\%). Found: C 43.53, $\mathrm{H} 3.08, \mathrm{~N}$ 1.66. Calculated for $\mathrm{C}_{63} \mathrm{H}_{53} \mathrm{AlF}_{42} \mathrm{O}_{4} \mathrm{MgN}_{2}$ : C 43.21, H 3.05, N 1.60 .

\section{Synthesis of $\left[\left({ }^{\mathrm{Me}} \mathrm{BDI}\right) \mathrm{Ca}\left(\mathrm{C}_{6} \mathrm{D}_{6}\right)\right]\left[\mathrm{Al}\left(\mathrm{OC}\left(\mathrm{CF}_{3}\right)_{3}\right)_{4}\right](7)$}

$\left[\left({ }^{\mathrm{Me}} \mathrm{BDI}\right) \mathrm{CaN}\left(\mathrm{SiMe}_{3}\right)_{2}\right](30 \mathrm{mg}, 0.049 \mathrm{mmol})$ and $\left[\mathrm{Ph}_{3} \mathrm{C}\right][\mathrm{Al}(\mathrm{OC}$ $\left.\left.\left(\mathrm{CF}_{3}\right)_{3}\right)_{4}\right](59 \mathrm{mg}, 0.049 \mathrm{mmol})$ were dissolved in $\mathrm{C}_{6} \mathrm{D}_{6}(0.5 \mathrm{~mL})$ in a sealed J. Young NMR tube, with the appearance of two immiscible phases. Colourless crystals of 7 suitable for X-ray analysis were formed by slow diffusion of hexane into the reaction mixture. Yield: $59 \mathrm{mg}, 76 \% .{ }^{19} \mathrm{~F}\left\{{ }^{1} \mathrm{H}\right\}$ NMR $(470 \mathrm{MHz}$, $\left.\mathrm{C}_{6} \mathrm{D}_{6}, 298 \mathrm{~K}\right): \delta-74.80 \mathrm{ppm}$ (s). Elemental analysis (\%). Found:


$\left([(\mathrm{BDI}) \mathrm{Ca}]\left[\mathrm{Al}\left(\mathrm{OC}\left(\mathrm{CF}_{3}\right)_{3}\right)_{4}\right]\right): \mathrm{C} 37.30, \mathrm{H} 2.85, \mathrm{~N} 1.93$.

\section{Synthesis of $\left[\left({ }^{\mathrm{Me}} \mathrm{BDI}\right) \mathrm{Ca}\left(\mathrm{C}_{4} \mathrm{D}_{8} \mathrm{O}\right)_{3}\right]\left[\mathrm{Al}\left(\mathrm{OC}\left(\mathrm{CF}_{3}\right)_{3}\right)_{4}\right](7 \cdot \mathrm{THF})$}

$\left[\left({ }^{\mathrm{Me}} \mathrm{BDI}\right) \mathrm{Ca}\left(\mathrm{C}_{6} \mathrm{D}_{6}\right)\right]\left[\mathrm{Al}\left(\mathrm{OC}\left(\mathrm{CF}_{3}\right)_{3}\right)_{4}\right](30 \mathrm{mg}, 0.049 \mathrm{mmol})$ was dissolved in THF- $d_{8}(0.5 \mathrm{~mL})$ in a sealed J. Young NMR tube. Colourless crystals of 7.THF suitable for X-ray analysis were formed by slow diffusion of hexane into the reaction mixture. Yield: $29 \mathrm{mg}, 94 \% .{ }^{1} \mathrm{H}$ NMR $\left(500 \mathrm{MHz}\right.$, THF- $\left.d_{8}, 298 \mathrm{~K}\right): \delta 7.23$ (d, $\left.{ }^{3} J_{\mathrm{HH}}=7.7 \mathrm{~Hz}, 4 \mathrm{H}, o, m-\mathrm{CH} \mathrm{Dipp}\right), 7.15\left(\mathrm{t},{ }^{3} J_{\mathrm{HH}}=7.7 \mathrm{~Hz}, 2 \mathrm{H}\right.$, p-CH Dipp), 4.98 (s, 1H, CH\{C(Me)NDipp $\}_{2}$ ), 3.10 (hept, ${ }^{3} J_{\mathrm{HH}}=$ $\left.6.9 \mathrm{~Hz}, 4 \mathrm{H}, \mathrm{CH}\left(\mathrm{CH}_{3}\right)_{2}\right), 1.73$ (s, 6H, $\left.\mathrm{CH}\left\{\mathrm{C}\left(\mathrm{CH}_{3}\right) \mathrm{NDipp}\right\}_{2}\right)$, $1.24 \mathrm{ppm}\left(2 \mathrm{~d},{ }^{3} J_{\mathrm{HH}}=6.9 \mathrm{~Hz}, 24 \mathrm{H}, \mathrm{CH}\left(\mathrm{CH}_{3}\right)_{2}\right) .{ }^{13} \mathrm{C}\left\{{ }^{1} \mathrm{H}\right\} \mathrm{NMR}$ (126 MHz, THF- $d_{8}, 298 \mathrm{~K}$ ): $\delta 168.0$ (s, NC(Me)), 147.5 (s, N-C Dipp), 142.6 (s, $C-{ }^{\mathrm{i}} \mathrm{Pr}$ ), 125.9 (s, $p$ - $C \mathrm{H}$ Dipp), 125.0 (s, o, $m-\mathrm{CH}$ Dipp), 95.6 (s, $\left.\mathrm{CH}\{\mathrm{C}(\mathrm{Me}) \mathrm{NDipp}\}_{2}\right), 29.3$ (s, $\left.\mathrm{CH}\left(\mathrm{CH}_{3}\right)_{2}\right), 25.1$ (s,

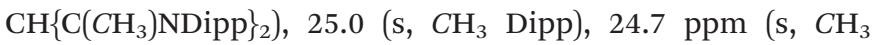
Dipp). ${ }^{19} \mathrm{~F}\left\{{ }^{1} \mathrm{H}\right\}$ NMR (470 MHz, THF- $\left.d_{8}, 298 \mathrm{~K}\right): \delta-74.02 \mathrm{ppm}(\mathrm{s})$. Elemental analysis (\%). Found: $\mathrm{C}$ 38.83, H 3.27, N 2.01. Calculated for $\mathrm{C}_{49} \mathrm{H}_{49} \mathrm{AlCaF}_{36} \mathrm{O}_{5} \mathrm{~N}_{2} \quad\left(\left[(\mathrm{BDI}) \mathrm{Ca}\left(\mathrm{C}_{4} \mathrm{D}_{8} \mathrm{O}\right)\right][\mathrm{Al}(\mathrm{OC}\right.$ $\left.\left.\left.\left(\mathrm{CF}_{3}\right)_{3}\right)_{4}\right]\right): \mathrm{C} 39.32, \mathrm{H} 3.30, \mathrm{~N} 1.87$.

\section{Synthesis of 8}

$\left[\mathrm{Ph}_{3} \mathrm{C}\right]\left[\mathrm{Al}\left(\mathrm{OC}\left(\mathrm{CF}_{3}\right)_{3}\right)_{4}\right](91 \mathrm{mg}, 0.075 \mathrm{mmol})$ and $\mathrm{KN}\left(\mathrm{SiMe}_{3}\right)_{2}$ $(15 \mathrm{mg}, 0.075 \mathrm{mmol})$ were dissolved in $\mathrm{C}_{6} \mathrm{D}_{6}(0.5 \mathrm{~mL})$ in a sealed J. Young NMR tube and vigorously stirred for 1 minute, forming a pink solution. The solvent was evaporated to dryness and the resulting residue extracted in hexane and filtered. ${ }^{1} \mathrm{H}$ NMR (400 MHz, $\left.\mathrm{C}_{6} \mathrm{D}_{6}, 298 \mathrm{~K}\right): \delta 7.27-7.23(4 \mathrm{H}, o-\mathrm{CH}$ $\mathrm{Ph}), 7.14-7.09(4 \mathrm{H}, m-\mathrm{CH} \mathrm{Ph}), 7.07-7.02(2 \mathrm{H}, p-\mathrm{CH} \mathrm{Ph}), 6.61$ $\left(\mathrm{dd},{ }^{3} J_{\mathrm{HH}}=10.2,{ }^{5} J_{\mathrm{HH}}=2.5 \mathrm{~Hz}, 2 \mathrm{H}, H \mathrm{C}=\mathrm{CHCHN}\right), 5.73(\mathrm{dd}$, $\left.{ }^{3} J_{\mathrm{HH}}=10.2,{ }^{4} J_{\mathrm{HH}}=3.8 \mathrm{~Hz}, 2 \mathrm{H}, H \mathrm{C}-\mathrm{CHN}\right), 4.54\left({ }^{3} J_{\mathrm{HH}}=10.3\right.$, $2.5 \mathrm{~Hz}, 1 \mathrm{H}, H \mathrm{C}-\mathrm{N}), 0.20 \mathrm{ppm}\left(\mathrm{s}, 18 \mathrm{H}, \mathrm{CH}_{3}\right) .{ }^{13} \mathrm{C}\left\{{ }^{1} \mathrm{H}\right\} \mathrm{NMR}$ $\left(126 \mathrm{MHz}, \mathrm{C}_{6} \mathrm{D}_{6}, 298 \mathrm{~K}\right): \delta 142.3$ (s, $\left.C_{\text {ipso }} \mathrm{Ph}\right), 140.4$ (s, $=\mathrm{CPh}_{2}$ ), 
$135.5(\mathrm{~s},=C-\mathrm{CHN}), 131.2(\mathrm{~s}, o-C \mathrm{H} \mathrm{Ph}), 128.4(\mathrm{~s}, m-C \mathrm{H} \mathrm{Ph})$, 127.5 (s, $p-C H \mathrm{Ph}), 126.5(\mathrm{~s}, C=\mathrm{C}-\mathrm{CHN}), 53.2(\mathrm{~s}, \mathrm{HCN})$, $3.3 \mathrm{ppm}$ (broad, $\mathrm{SiCH}_{3}$ ). ${ }^{29} \mathrm{Si}\left\{{ }^{1} \mathrm{H}\right\} \mathrm{NMR}\left(99.4 \mathrm{MHz}, \mathrm{C}_{6} \mathrm{D}_{6}\right.$, $298 \mathrm{~K}): \delta 6.21 \mathrm{ppm}$.

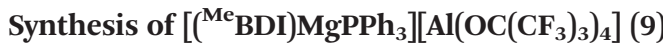

In a sealed J. Young NMR tube, $\left[\left({ }^{\mathrm{Me}} \mathrm{BDI}\right) \mathrm{Mg}\left(\mathrm{C}_{6} \mathrm{D}_{5} \mathrm{CD}_{3}\right)\right][\mathrm{Al}(\mathrm{OC}$ $\left.\left.\left(\mathrm{CF}_{3}\right)_{3}\right)_{4}\right]$ (81 $\mathrm{mg}, 0.054 \mathrm{mmol}$ ) was dissolved in toluene- $d_{8}$ $(0.5 \mathrm{~mL})$ and vigorously stirred for 1 minute with the appearance of two immiscible phases. The resulting mixture was subsequently treated with one equivalent of triphenylphosphine (14 mg, $0.054 \mathrm{mmol}$ ) and vigorously stirred for another minute. Colourless crystals of $\mathbf{9}$ suitable for X-ray analysis were formed by slow diffusion of hexane into the reaction mixture. Yield: $66 \mathrm{mg}, 74 \% .{ }^{1} \mathrm{H}$ NMR (500 MHz, tol- $d_{8}, 298 \mathrm{~K}$ ): $\delta$ 7.14-6.89 (21H, CH Dipp and $\left.\mathrm{PPh}_{3}\right), 4.95$ (s, 1H, CH\{C(Me) $\mathrm{NDipp}_{2}$ ), 2.71 (hept, $\left.{ }^{3} J_{\mathrm{HH}}=6.9 \mathrm{~Hz}, 4 \mathrm{H}, \mathrm{CH}\left(\mathrm{CH}_{3}\right)_{2}\right), 1.51(\mathrm{~s}, 6 \mathrm{H}$, $\mathrm{CH}\left\{\mathrm{C}\left(\mathrm{CH}_{3}\right) \mathrm{NDipp}_{2}\right), 1.04\left(\mathrm{~d},{ }^{3} J_{\mathrm{HH}}=6.9 \mathrm{~Hz}, 12 \mathrm{H}, \mathrm{CH}\left(\mathrm{CH}_{3}\right)_{2}\right)$, $0.62 \mathrm{ppm}\left(\mathrm{d},{ }^{3} \mathrm{~J}_{\mathrm{HH}}=6.9 \mathrm{~Hz}, 12 \mathrm{H}, \mathrm{CH}\left(\mathrm{CH}_{3}\right)_{2}\right) \cdot{ }^{13} \mathrm{C}\left\{{ }^{1} \mathrm{H}\right\} \mathrm{NMR}$ (126 MHz, tol- $\left.d_{8}, 298 \mathrm{~K}\right): \delta 173.4$ (s, NC(Me)), $144.4\left(\mathrm{~s}, C-{ }^{\mathrm{i}} \mathrm{Pr}\right)$, 142.0 (s, N-CMe), 141.8 (s, N-C Dipp), 133.8-125.2 (CH Dipp and $\mathrm{Ph}$ ), 97.4 (s, $\left.\mathrm{CH}\{\mathrm{C}(\mathrm{Me}) \mathrm{NDipp}\}_{2}\right), 29.3\left(\mathrm{~s}, \mathrm{CH}\left(\mathrm{CH}_{3}\right)_{2}\right), 24.5$ (s, $\mathrm{CH}_{3}$ Dipp), 23.7 (s, CH-CH $\mathrm{CH}_{3}$ Dipp), $23.1 \mathrm{ppm}$ (s, $\mathrm{CH}_{3}$ Dipp). ${ }^{31} \mathrm{P}\left\{{ }^{1} \mathrm{H}\right\}$ NMR $\left(125.8 \mathrm{MHz}\right.$, tol- $\left.d_{8}, 298 \mathrm{~K}\right): \delta-4.9 \mathrm{ppm} .{ }^{19} \mathrm{~F}\left\{{ }^{1} \mathrm{H}\right\}$ NMR (470 MHz, tol- $\left.d_{8}, 298 \mathrm{~K}\right): \delta-74.84$ ppm. Elemental analysis (\%). Found: $\mathrm{C} 44.97, \mathrm{H} 3.49, \mathrm{~N} 1.63$. Calculated for $\mathrm{C}_{63} \mathrm{H}_{56} \mathrm{AlF}_{36} \mathrm{O}_{4} \mathrm{MgN}_{2} \mathrm{P}: \mathrm{C} 45.27, \mathrm{H} 3.38, \mathrm{~N} 1.68$.

\section{Synthesis of $\left[\left({ }^{t-\mathrm{Bu}} \mathrm{BDI}\right) \mathrm{MgPPh}_{3}\right]\left[\mathrm{Al}\left(\mathrm{OC}\left(\mathrm{CF}_{3}\right)_{3}\right)_{4}\right](\mathbf{1 0})$}

$\left[\left({ }^{t-\mathrm{Bu}} \mathrm{BDI}\right) \mathrm{Mg}\left(\mathrm{C}_{6} \mathrm{D}_{5} \mathrm{CD}_{3}\right)\right]\left[\mathrm{Al}\left(\mathrm{OC}\left(\mathrm{CF}_{3}\right)_{3}\right)_{4}\right]\left(\begin{array}{lll}82 \mathrm{mg}, & 0.052 \mathrm{mmol})\end{array}\right.$ was dissolved in toluene- $d_{8}(0.5 \mathrm{~mL})$ in a sealed J. Young NMR tube and vigorously stirred for 1 minute, with the appearance of two immiscible phases. The resulting mixture was subsequently treated with one equivalent of triphenylphosphine (14 mg, $0.052 \mathrm{mmol}$ ) and vigorously stirred for another minute. Colourless crystals of $\mathbf{1 0}$ suitable for X-ray crystallography were grown by slow diffusion of hexane into the reaction mixture. Yield: $70 \mathrm{mg}, 77 \% .{ }^{31} \mathrm{P}\left\{{ }^{1} \mathrm{H}\right\} \mathrm{NMR}\left(125.8 \mathrm{MHz}\right.$, tol- $d_{8}$, $298 \mathrm{~K}):-4.6 \mathrm{ppm} .{ }^{19} \mathrm{~F}\left\{{ }^{1} \mathrm{H}\right\}$ NMR (470 MHz, tol- $\left.d_{8}, 298 \mathrm{~K}\right)$ : $\delta-74.84$ ppm. Elemental analysis (\%). Found: C 46.61, H 4.08, $\mathrm{N}$ 1.76. Calculated for $\mathrm{C}_{69} \mathrm{H}_{68} \mathrm{AlF}_{36} \mathrm{O}_{4} \mathrm{MgN}_{2} \mathrm{P}: \mathrm{C}$ 47.21, H 3.90, $\mathrm{N} 1.60$.

\section{Conflicts of interest}

The authors declare no competing financial interests.

\section{Acknowledgements}

We thank the EPSRC (UK) for funding this research (grant number: EP/N014456/1).

\section{References}

1 D. A. Dougherty, Science, 1996, 271, 163-168.

2 J. C. Ma and D. A. Dougherty, Chem. Rev., 1997, 97, 13031324.

3 A. S. Mahadevi and G. N. Sastry, Chem. Rev., 2013, 113, 2100-2138.

4 S. E. Rodriguez-Cruz and E. R. Williams, J. Am. Soc. Mass Spectrom., 2001, 12, 250-257.

5 S. Tsuzuki, T. Uchimaru and M. Mikami, J. Phys. Chem. A, 2003, 107, 10414-10418.

6 A. S. Reddy and G. N. Sastry, J. Phys. Chem. A, 2005, 109, 8893-8903.

7 A. S. Reddy, H. Zipse and G. N. Sastry, J. Phys. Chem. B, 2007, 111, 11546-11553.

8 T. Rocha-Rinza and J. Hernandez-Trujillo, Chem. Phys. Lett., 2006, 422, 36-40.

9 T. C. Dinadayalane, A. Hassan and J. Leszczynski, J. Mol. Struct., 2010, 976, 320-323.

10 T. C. Dinadayalane, A. Hassan and J. Leszczynski, Theor. Chem. Acc., 2012, 131, 1131.

11 A. Mirchi, N. Sizochenko, T. Dinadayalane and J. Leszczynski, J. Phys. Chem. A, 2017, 121, 8927-8938.

12 P. Kadlubanski, K. Calderon-Mojica, W. A. Rodriguez, D. Majumdar, S. Roszak and J. Leszczynski, J. Phys. Chem. A, 2013, 117, 7989-8000.

13 C. Loh, S. Seupel, H. Gorls, S. Krieck and M. Westerhausen, Organometallics, 2014, 33, 1480-1491.

14 C. Loh, S. Seupel, A. Koch, H. Gorls, S. Krieck and M. Westerhausen, Dalton Trans., 2014, 43, 14440-14449.

15 S. C. Rosca, C. Dinoi, E. Caytan, V. Dorcet, M. Etienne, J. F. Carpentier and Y. Sarazin, Chem. - Eur. J., 2016, 22, 6505-6509.

16 S. C. Rosca, E. Caytan, V. Dorcet, T. Roisnel, J. F. Carpentier and Y. Sarazin, Organometallics, 2017, 36, 1269-1277.

17 W. D. Buchanan, D. G. Allis and K. Ruhlandt-Senge, Chem. Commun., 2010, 46, 4449-4465.

18 S. C. Rosca, V. Dorcet, T. Roisnel, J. F. Carpentier and Y. Sarazin, Dalton Trans., 2017, 46, 14785-14794.

19 S. C. Rosca, V. Dorcet, J. F. Carpentier and Y. Sarazin, Inorg. Chim. Acta, 2018, 475, 59-64.

20 H. Schumann, S. Schutte, H. J. Kroth and D. Lentz, Angew. Chem., Int. Ed., 2004, 43, 6208-6211.

21 B. Freitag, H. Elsen, J. Pahl, G. Ballmann, A. Herrera, R. Dorta and S. Harder, Organometallics, 2017, 36, 18601866.

22 R. A. Williams and T. P. Hanusa, J. Am. Chem. Soc., 1990, 112, 2454-2455.

23 L. Bonomo, E. Solari, R. Scopelliti and C. Floriani, Chem. Eur. J., 2001, 7, 1322-1332.

24 H. Lehmkuhl, K. Mehler, R. Benn, A. Rufinska and C. Kruger, Chem. Ber., 1986, 119, 1054-1069.

25 E. Hey, L. M. Engelhardt, C. L. Raston and A. H. White, Angew. Chem., Int. Ed. Engl., 1987, 26, 81-82.

26 M. Westerhausen and W. Schwarz, Z. Anorg. Allg. Chem., 1994, 620, 304-308. 
27 M. Westerhausen, M. H. Digeser, H. Noth, T. Seifert and A. Pfitzner, J. Am. Chem. Soc., 1998, 120, 6722-6725.

28 M. Westerhausen, M. Krofta and A. Pfitzner, Inorg. Chem., 1999, 38, 598.

29 M. Westerhausen, M. H. Digeser, B. Wieneke, H. Noth and J. Knizek, Eur. J. Inorg. Chem., 1998, 517-521.

30 S. Blair, K. Izod and W. Clegg, Inorg. Chem., 2002, 41, 38863893.

31 S. Blair, K. Izod, W. Clegg and R. W. Harrington, Eur. J. Inorg. Chem., 2003, 3319-3324.

32 M. Gartner, H. Gorls and M. Westerhausen, Inorg. Chem., 2008, 47, 1397-1405.

33 B. M. Day and M. P. Coles, Eur. J. Inorg. Chem., 2010, 54715477.

34 M. Arrowsmith, M. S. Hill, A. L. Johnson, G. Kociok-Kohn and M. F. Mahon, Angew. Chem., Int. Ed., 2015, 54, 78827885.

35 M. J. Taylor, M. P. Coles and J. R. Fulton, Aust. J. Chem., 2015, 68, 635-640.

36 A. Pape, M. Lutz and G. Muller, Angew. Chem., Int. Ed. Engl., 1994, 33, 2281-2284.

37 D. E. Gindelberger and J. Arnold, Inorg. Chem., 1994, 33, 6293-6299.

38 J. Pahl, S. Brand, H. Elsen and S. Harder, Chem. Commun., 2018, 54, 8685-8688.

39 J. Pahl, H. Elsen, A. Friedrich and S. Harder, Chem. Commun., 2018, 54, 7846-7849.

40 A. S. S. Wilson, M. S. Hill, M. F. Mahon, C. Dinoi and L. Maron, Science, 2017, 358, 1168-1171.

41 B. Liu, V. Dorcet, L. Maron, J. F. Carpentier and Y. Sarazin, Eur. J. Inorg. Chem., 2012, 3023-3031.

42 I. Krossing and A. Reisinger, Coord. Chem. Rev., 2006, 250, 2721-2744.

43 A. B. A. Rupp and I. Krossing, Acc. Chem. Res., 2015, 48, 2537-2546.

44 T. A. Engesser, M. R. Lichtenthaler, M. Schleep and I. Krossing, Chem. Soc. Rev., 2016, 45, 789-899.

45 J. L. Atwood and J. D. Atwood, Adv. Chem. Ser., 1976, 112127.

46 M. S. Hill, G. Kociok-Koehn and D. J. MacDougall, Inorg. Chem., 2011, 50, 5234-5241.

47 M. D. Anker, M. Arrowsmith, P. Bellham, M. S. Hill, G. Kociok-Kohn, D. J. Liptrot, M. F. Mahon and C. Weetman, Chem. Sci., 2014, 5, 2826-2830.

48 M. D. Anker, M. Arrowsmith, R. L. Arrowsmith, M. S. Hill and M. F. Mahon, Inorg. Chem., 2017, 56, 5976-5983.

49 M. W. Bouwkamp, J. de Wolf, I. D. Morales, J. Gercama, A. Meetsma, S. I. Troyanov, B. Hessen and J. H. Teuben, J. Am. Chem. Soc., 2002, 124, 12956-12957.
50 M. W. Bouwkamp, P. H. M. Budzelaar, J. Gercama, I. D. Morales, J. de Wolf, A. Meetsma, S. I. Troyanov, J. H. Teuben and B. Hessen, J. Am. Chem. Soc., 2005, 127, 14310-14319.

51 F. Basuli, H. Aneetha, J. C. Huffman and D. J. Mindiola, J. Am. Chem. Soc., 2005, 127, 17992-17993.

52 S. D. Pike, M. R. Crimmin and A. B. Chaplin, Chem. Commun., 2017, 53, 3615-3633.

53 O. Eisenstein, J. Milani and R. N. Perutz, Chem. Rev., 2017, 117, 8710-8753.

54 L. J. Radonovich, E. C. Zuerner, H. F. Efner and K. J. Klabunde, Inorg. Chem., 1976, 15, 2976-2981.

55 A. K. Renfrew, A. D. Phillips, E. Tapavicza, R. Scopelliti, U. Rothlisberger and P. J. Dyson, Organometallics, 2009, 28, 5061-5071.

56 B. R. Jagirdar, K. J. Klabunde, R. Palmer, L. J. Radonovich and T. Williams, Inorg. Chim. Acta, 1996, 250, 317-326.

57 A. Khaleel and K. J. Klabunde, Inorg. Chem., 1996, 35, 3223-3227.

58 M. Carrasco, N. Curado, E. Alvarez, C. Maya, R. Peloso, M. L. Poveda, A. Rodriguez, E. Ruiz, S. Alvarez and E. Carmona, Chem. - Eur. J., 2014, 20, 6092-6102.

59 P. G. Williard and Q. Y. Liu, J. Org. Chem., 1994, 59, 15961597.

60 M. Rauch, S. Ruccolo, J. P. Mester, Y. Rong and G. Parkin, Chem. Sci., 2016, 7, 142-149.

61 H. J. Hao, H. W. Roesky, Y. Q. Ding, C. M. Cui, M. Schormann, H. G. Schmidt, M. Noltemeyer and B. Zemva, J. Fluorine Chem., 2002, 115, 143-147.

62 N. L. Lampland, A. Pindwal, S. R. Neal, S. Schlauderaff, A. Ellern and A. D. Sadow, Chem. Sci., 2015, 6, 6901-6907.

63 L. Cabrera, G. C. Welch, J. D. Masuda, P. R. Wei and D. W. Stephan, Inorg. Chim. Acta, 2006, 359, 3066-3071.

64 C. N. de Bruin-Dickason, T. Sutcliffe, C. A. Lamsfus, G. B. Deacon, L. Maron and C. Jones, Chem. Commun., 2018, 54, 786-789.

65 M. Kaupp, Angew. Chem., Int. Ed., 2001, 40, 3534-3565.

66 G. Jeung, J. P. Daudey and J. P. Malrieu, Chem. Phys. Lett., 1983, 98, 433-438.

67 X. Wu, L. L. Zhao, D. D. Jiang, I. Fernandez, R. Berger, M. F. Zhou and G. Frenking, Angew. Chem., Int. Ed., 2018, 57, 3974-3980.

68 A. P. Dove, V. C. Gibson, P. Hormnirun, E. L. Marshall, J. A. Segal, A. J. P. White and D. J. Williams, Dalton Trans., 2003, 3088-3097.

69 V. Balasanthiran, M. H. Chisholm, K. Choojun, C. B. Durr and P. M. Wambua, Polyhedron, 2016, 103, 235-240.

70 M. R. Crimmin, M. S. Hill, P. B. Hitchcock and M. F. Mahon, New J. Chem., 2010, 34, 1572-1578. 